U. S. DEPARTMENT OF COMMERCE NATIONAL BUREAU OF STANDARDS

AMERICAN STANDARD BUILDING CODE REQUIREMENTS FOR MINIMUM DESIGN LOADS IN BUILD. INGS AND OTHER STRUCTURES

MISCELLANEOUS PUBLICATION M179 



\section{U. S. DEPARTMENT OF COMMERCE}

. HENRY A. WALLACE, Secretary

NATIONAL BUREAU OF STANDARDS

LYMAN J. BRIGGS, Director

NATIONAL BUREAU OF STANDARDS MISCELLANEOUS PUBLICATION M179

\section{AMERICAN STANDARD BUILDING CODE REQUIREMENTS FOR MINIMUM DESIGN LOADS IN BUILDINGS AND OTHER STRUCTURES}

By

Sectional Committee on Building Code Requirements for Minimum Design Loads in Buildings-A58

Under the Sponsorship of the National Bureau of Standards

Issued October 18, 1945

Approved

June 19, 1945, by the American Standards Association

as American Standard A58.1-1945

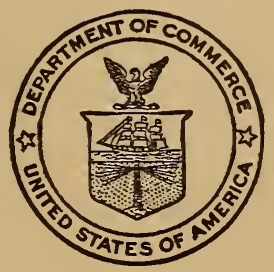

UNITED STATES

GOVERNMENT PRINTING OFFICE

WASHINGTON : 1945 



\section{FOREWORD}

In the design of buildings it is necessary to use certain assumptions regarding the weight of the materials used and of the building contents, as well as the external forces to which the structure may be subjected. Building codes set minimum values that are to be assumed under given conditions. In this standard a committee chosen for its special knowledge of the subject has recorded its recommendations on assumptions as to dead, live, wind, and earthquake loads.

The standard is one of a series presenting recommended building code requirements that are being developed by technical committees under the procedure of the American Standards Association. The general building code program is under the supervision of the Building Code Correlating Committee of the Association.

The objectives of the program and information concerning the several technical committees and the Building Code Correlating Committee are given in an announcement, Building Code Standardization, which may be obtained from the American Standards Association.

Lyman J. Briggs, Director 


\section{SECTIONAL COMMITTEE}

The personnel of the Sectional Committee on Building Code Requirements for Minimum Design Loads in Buildings-A58, which developed the standard, is as follows:

National Bureau of Standards, Sponsor. George N. Thompson, Chairman. J. H. Courtney, Secretary.

\section{Organization represented}

Representative

American Institute of Architects. .............. Levon SERoN.

Theodore I. Coe

(Alternate):

American Society of Civil Engineers _.......... JAMES L. EDwards.

Building Officials Conference of America......... William D. Guion.

JAMES A. EASTON

(Alternate).

Coast and Geodetic Survey, U. S. Department of

Federal Works Agency, Public Buildings Administration

National Bureau of Standards, U. S. Department of

Pacific Coast Building Officials Conference

Members-at-Large.
Frank Neumann.

Charles W. Barber. K. LEE HYder.

George N. Thompson. Hal Colling. Joseph W. Degen. Henry D. Dewell. Hugh L. Dryden.

R. R. Martel.

David Lee Narver. Arthur C. Ruge.

C. A. Willson.

Walker S. Lee, vice chairman, and J. H. Courtney, technical secretary, of the ASA Building Code Correlating Committee, serve as ex-officio members of this committee in order to coordinate the requirements of the standard with others in the building code program.

Iv 


\section{O N T E N T S}

Foreword

Sectional Committee

Section 1. General

1-1. Scope

1-2. Definitions

1-3. Safe support required.

1-4. Additions to existing structures....

Section 2. Dead LoADS . . $2-1$. Weights of materials and constructions

2-2. Weight of building equipment

SECTION 3. LIVE LoadS . 3-1. Uniformly distributed floor loads

3-2. Provision for partitions

3-3. Concentrated loads...

3-4. Partial loading

3-5. Impact loads

3-6. Reduction of live load

3-7. Restrictions on loading

3-8. Posting of live loads...

3-9. Roof loads (including snow loads)

3-10. Other live loads

3-11. Load tests

Section 4. Soll and Hydrostatic Pressures

4-1. Pressure on basement walls

4-2. Uplift on floors

Section 5. Wind LoAdS

5-1. Minimum design pressures

5-2. Exterior walls

5-3. Roofs

5-4. Chimneys

5-5. Signs

5-6. Other structures

5-7. Shielding and unusual exposures

5-8. Combined stresses.....

5-9. Overturning and sliding

5-10. Stresses during erection

Section 6. EARThQUAKE LoAdS-General

6-1. Minimum lateral load . . .

6-2. Combined stresses...

6-3. Horizontal torsional moments

6-4. Distribution of horizontal shear

6-5. Special requirements

Section 7. EARThQUAKe Loads-Major EarthQUAKES

7-1. Minimum lateral load

7-2. Resistance of skeleton frame

7-3. Combined stresses........

7-4. Horizontal torsional moments

7-5. Distribution of horizontal shear

7-6. Connections

7-7. Utilization of permanent structural elements

APPENDIX . . .

General $2-1$. Weights of materials and constructions Range in weights 3-1 (a). Uniformly distributed floor loads. 3-6. Reduction of live load

3-9. Roof loads (including snow loads)

3-11. Load tests

5-1. Minimum design wind pressures.

5-2. Exterior walls

5-3. Roofs

5-4. Chimneys.......

5-5. Signs

6 and 7 . Earthquake loads

Earthquakes in the United States. 
1. Minimum design dead loads

2. Minimum uniformly distributed live loads

3. Minimum design loads for materials.....

FIGURES

1. Snow loads

3. Earthquakes of destructive intensity 


\title{
American Standard Building Code Requirements for Minimum Design Loads in Buildings and Other: Structures
}

By

\begin{abstract}
Sectional Committee on Building Code Requirements for Minimum Design Loads in Buildings-A58
\end{abstract}

Under the Sponsorship of the National Bureau of Standards

ABSTRACT

Building Code Requirements for Minimum Design Loads in Buildings and Other Structures (ASA-A58.1-1945) gives assumptions for dead, live, wind, and earthquake loads suitable for inclusion in building codes. This document, prepared by American Standards Association Sectional Committee A58 under the sponsorship of the National Bureau of Standards, is one of a series of building code standards prepared by various committees under the jurisdiction of the Building Code Correlating Committee of the American Standards Association. The basis of the requirements is discussed in an appendix, which also gives supplementary information useful to those engaged in preparing and administering local building codes.

\section{SECTION 1. GENERAL}

1-1. Scope.-These requirements are intended to govern assumptions for dead, live, and other loads in the design of buildings and other structures which are subject to building code requirements.

\section{1-2. Definitions.}

Building official means the officer or other person charged with the administration and enforcement of the building code, or his duly authorized representative.

Dead load means the weight of all permanent construction and equipment, including walls, framing, floors, roofs, permanent partitions, and stairways, of a building or other structure.

Live load means the load imposed by the occupancy.

Nоте.-The live load does not include the wind load or earthquake load.

1-3. Safe Support Required.-Buildings or other structures, and all parts thereof, shall be designed and construoted to support safely all loads, including dead loads, without exceeding the allowable stresses prescribed for the materials of construction in the structural members. 1-4. Additions to Existing Structures.-When an existing building or other structure is enlarged or otherwise altered, all portions thereof affected by such enlargement or alteration shall be strengthened, if necessary, so that all loads will be supported safely without exceeding the allowable stresses prescribed for the materials of construction in the structural members. 


\section{SECTION 2. DEAD LOADS}

2-1. Weights of Materials and Constructions:-In estimating dead loads for purposes of design, the actual weights of materials and constructions shall be used, provided that in the absence of definite information values satisfactory to the building official may be assumed.

Nоте.-For information on dead loads, see appendix, table 1.

2-2. Weight of Building Equipment.-In estimating dead loads for purposes of design, the weight of plumbing stacks and risers, electric feeders, and ventilating and air-conditioning systems shall be included whenever any of these are carried by structural members.

\section{SECTION 3. LIVE LOADS}

\section{3-1. Uniformly Distributed Floor Loads.}

(a) The live loads assumed for purposes of design shall be the greatest loads that probably will be produced by the intended occupancies or uses, provided that the live loads to be considered as uniformly distributed shall be not less than the values given in the following table:

Apartment houses:

OCCUPANCY OR USE

Private apartments

LIVE LOAD

Public stairways

$l b / f t^{2}$
40

100

Assembly halls:

Fixed seats

60

Movable seats

100

Corridors, upper floors

Corridors:

First floor

Other floors, same as occupancy served except as indicated.

Courtrooms

Dance halls

Dining rooms, public

Dwellings.

Hospitals and asylums:

Operating rooms

Private rooms

Wards

Hotels:

Public space

Guest rooms

Corridors serving public rooms

Public rooms

Loft buildings

Manufacturing, light.

Office buildings:

Offices

Schools:

Lobbies... 100

Classrooms

Corridors

Theaters:

Aisles, corridors, and lobbiês.

Orchestra floor, and lobies

Balconies...

Stage floor 
(b) When occupancies or uses not listed above are involved, the live load shall be determined in a manner satisfactory to the building official.

Note.-For information on live loads, see appendix, table 2.

3-2. Provision for Partitions.-In office buildings or other buildings where partitions might be subject to erection or rearrangement, provision for partition weight shall be made, whether or not partitions are shown on the plans, unless the specified live load exceeds 80 pounds per square foot.

3-3. Concentrated Loads.-In the design of floors, consideration shall be given to the effects of known or probable concentrations of load to which they may be subjected. Floors shall be designed to carry the specified distributed loads, or the following minimum concentrations, whichever may produce the greater stresses. The indicated concentrations shall be assumed to occupy areas $2 \frac{1}{2}$ feet square and to be so placed as to produce maximum stresses in the affected members.

Office floors, including corridors

Garages....

Trucking space within building

3-4. Partial Loading. - When the construction is such that the structural elements thereof act together in the nature of an elastic frame due to their continuity and the rigidity of the connections, and the live load exceeds 150 pounds per square foot or twice the dead load, the effect of partial live load such as will produce maximum stress in any member shall be provided for in the design.

3-5. Impact Loads. - The live loads specified in Section 3-1 (a) may be assumed to include a sufficient allowance to cover the effects of ordinary impact. For special occupancies and loads involving unusual impacts, such as those resulting from moving machinery, elevators, craneways, vehicles, etc., provision shall be made by a suitable increase in the assumed live load.

\section{3-6. Reduction of Live Load.}

(a) No reduction shall be applied to the roof live load.

(b) For live loads of 100 pounds or less per square foot, the design live load on any member supporting 150 square feet or more may be reduced at the rate of 0.08 percent per square foot of area supported by the member, except that no reduction shall be made for areas to be occupied as places of public assembly. The reduction shall exceed neither $R$ as determined by the following formula nor 60 percent:

in which

$$
R=100 \times \frac{D+L}{4.33 L}
$$

$R=$ reduction in percent

$D=$ dead load per square foot of area supported by the member

$L=$ design live load per square foot of area supported by the member.

For live loads exceeding 100 pounds per square foot, no reduction shall be made, except that the design live loads on columns may be reduced 20 percent.

3-7. Restrictions on Loading.- It shall be unlawful to place, or cause or permit to be placed, on any floor or roof of a building or other structure a load greater than that for which such floor or roof is designed.

$665106^{\circ}-45-2$ 
3-8. Posting of Live Loads.-In every building or other structure, or part thereof, used for mercantile, business, industrial, or storage purposes, the loads approved by the building official shall be marked on plates of approved design which shall be supplied and securely affixed by the owner of the building, or his duly authorized agent, in a conspicuous place in each space to which they relate. Such plates shall not be removed or defaced but, if lost, removed, or defaced, shall be replaced by the owner or his agent.

3-9. Roof Loads (including snow loads).

(a) Ordinary roofs, either flat or pitched, shall be designed for a load of not less than 20 pounds per square foot of horizontal projection in addition to the dead load, and in addition to either the wind or earthquake load, whichever produces the greater stresses.

Notr.-The figure of 20 pounds per square foot is a minimum. In preparing local codes, the map shown in figure 1 in the appendix should be consulted and the indicated snow load for the locality, if larger, substituted for this minimum.

(b) Roofs to be used for promenades shall be designèd for a minimum load of 60 pounds per square foot in addition to the dead load. Roofs to be used for other special purposes shall be designed for appropriate loads as directed or approved by the building official.

3-10. Other Live Loads.

(a) Stair treads shall be designed to support a uniformly distributed load of 100 pounds per square foot, or concentrated loads of 300 pounds spaced 3 feet center to center each occupying an area 1 foot wide by the depth of the tread, whichever will produce the greater stresses.

(b) Sidewalks shall be designed to support either a uniformly distributed load of 250 pounds per square foot, or a concentrated load of 8,000 pounds on an area $2 \frac{1}{2}$ feet square placed in any position, whichever will produce the greater stresses.

(c) Driveways shall be designed to support a uniformly distributed load of 100 pounds per square foot for vehicles weighing less than 3 tons with load, 150 pounds per square foot for vehicles weighing 3 to 10 tons with load, 200 pounds per square foot for vehicles weighing over 10 tons with load, or a concentrated load equal to the maximum expected wheel load on an area $2 \frac{1}{2}$ feet square placed in any position, whichever will produce the greater stresses.

(d) Accessible ceilings, scuttles, and ribs of skylights shall be designed to support a concentrated load of 200 pounds occupying an area $2 \frac{1}{2}$ feet square; and so placed as to produce maximum stresses in the affected members.

(e) Stairway and balcony railings, both exterior and interior, shall be designed to resist a horizontal thrust of 50 pounds per linear foot applied at the top of the railing.

3-11. Load Tests.- The building official may require a load test of any construction whenever there is reason to question its safety for the intended occupancy or use.

\section{SECTION 4. SOIL AND HYDROSTATIC PRESSURES}

4-1. Pressure on Basement Walls. - In the design of basement walls and similar approximately vertical structures below grade, provision shall be made for the lateral pressure of adjacent soil. Due allowance 
shall be made for possible surcharge from fixed or moving loads. When a portion, or the whole, of the adjacent soil is below a free-water surface, computations shall be based on the weight of the soil diminished by buoyancy, plus full hydrostatic pressure.

4-2. Uplift on Floors. - In the design of basement floors and similar approximately horizontal construction below grade, the upward pressure of water, if any, shall be taken as the full hydrostatic pressure applied over the entire area. The hydrostatic head shall be measured from the underside of the construction.

\section{SECTION 5. WIND LOADS}

5-1. Minimum Design Pressures.-Buildings or other structures shall be designed and constructed to withstand the horizontal pressures shown in the following table, allowing for wind from any direction. The height is to be measured above the average level of the ground adjacent to the building or structure.

Design wind pressures for various height zones of buildings or other structures

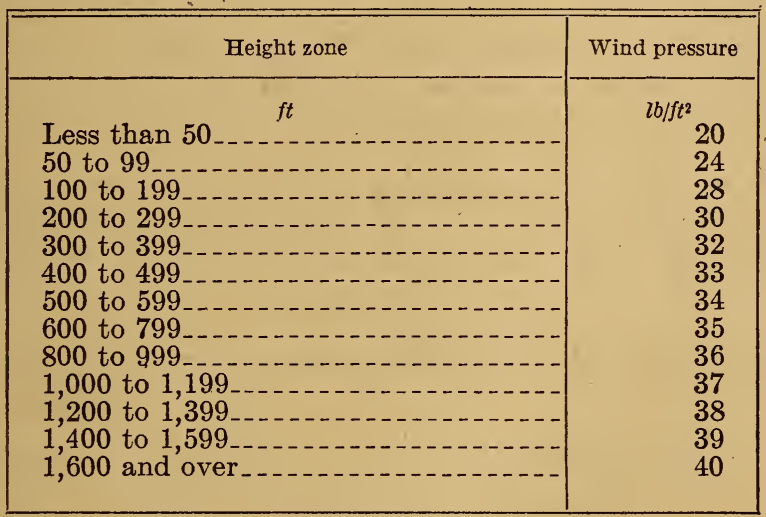

Notw.-The figures given are recommended as minimum. In preparing local codes, figure 2 and the accompanying discussion in the appendix should be consulted and larger figures substituted if necessary. These requirements do not provide for tornadoes. They are based on a design wind velocity of 75 miles per hour corresponding roughly to a 5 -minute average of 50 miles per hour (indicated 63 by a 4 -cup anemometer) at 30 feet from the ground.

5-2. Exterior Walls.-Every, exterior wall shall be designed and constructed to withstand the pressures specified in Section 5-1, Minimum Design Pressures, acting either inward or outward.

\section{5-3. Roofs.}

(a) The roofs of all buildings or other structures shall be designed and constructed to withstand pressures, acting outward normal to the surface, equal to $1 \frac{11}{4}$ times those specified for the corresponding height zone in which the roof is located. The height is to be taken as the mean height of the roof structure above the average level of the ground adjacent to the building or other structure, and the pressure assumed on the entire roof area.

(b) Roofs or sections of roofs with slopes greater than $30^{\circ}$ shall be designed and constructed to withstand pressures, acting inward normal 
to the surface, equal to those specified for the height zone in which the roof is located, and applied to the windward slope only.

(c) Overhanging eaves and cornices shall be designed and constructed to withstand outward pressures equal to twice those specified in Section 5-1, Minimum Design Pressures.

(d) Adequate anchorage of the roof to walls and columns, and of walls and columns to the foundations to resist overturning, uplift, and sliding, shall be provided in all cases.

5-4. Chimneys.-Chimneys, tanks, and towers shall be designed and constructed to withstand the pressures specified in Section 5-1, Minimum Design Pressures, multiplied by the following factors, depending on shape:

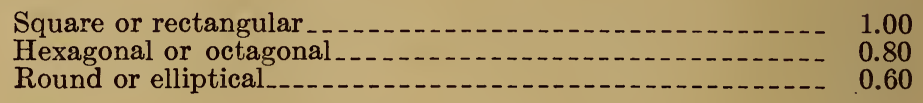

\section{5-5. Signs.}

(a) Signs in which the projected area exposed to wind consists of 70 percent or more of the gross area as determined by the over-all dimensions shall be classed as solid signs; those in which the projected exposed area is derived from open letters, figures, strips, and structural framing members, the aggregate total area of which is less than 70 percent of the gross area so determined, shall be classed as open signs.

(b) All signs shall be designed and constructed to withstand the horizontal pressures shown in the following table applied to the projected exposed area, allowing for wind from any direction:

Design wind pressures

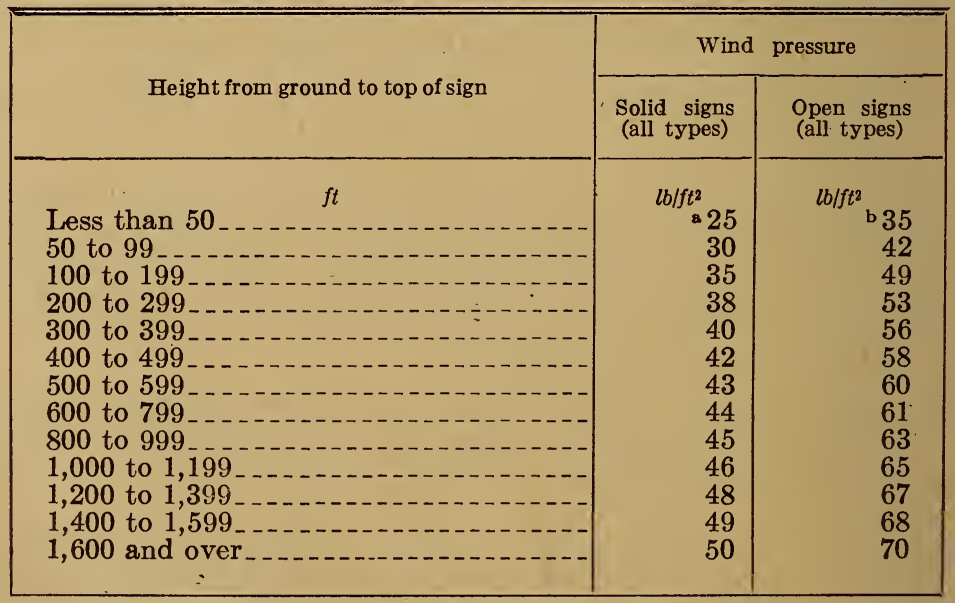

- Solid ground signs less than $50 \mathrm{ft}$ in height shall be designed and constructed to withstand a wind pressure of not less than $15 \mathrm{lb} / \mathrm{ft}^{2}$.

b Open ground signs less than $50 \mathrm{ft}$ in height shall be designed and constructed to withstand a wind pressure of not less than $25 \mathrm{lb} / \mathrm{ft}^{2}$.

Note.-Complete requirements for signs are being developed by Sectional Committee on Building Code Requirements for Signs and Outdoor Display Structures-A60. 
5-6. Other Structures. - The building official may require evidence to support the values for wind pressure used in the design of structures not specifically covered in this section.

5-7. Shielding and Unusual Exposures.

(a) No allowance shall be made for the shielding effect of other buildings or structures.

(b) If the building or other structure is on a mountain, ocean promontory, or in any other location considered by the building official to be unusually exposed, higher wind pressures may be, prescribed by the building official.

5-8. Combined Stresses.-For combined stresses due to wind, dead, live, and snow loads, the allowable stress may be increased $331 / 3$ percent provided the section thus found is at least as strong as that required for dead, live, and snow loads alone.

\section{5-9. Overturning and Sliding.}

(a) The overturning moment due to the wind load shall not exceed $66 \% \frac{2}{3}$ percent of the moment of stability of the building or other structure due to the dead load only, unless the building or other structure is anchored so as to resist the excess overturning moment without exceeding the allowable stresses for the materials used. The axis of rotation for computing the overturning moment and the moment of stability shall be taken as the intersection of the outside wall line on the leeward side and the plane representing the average elevation of the bottoms of the footings. The weight of earth superimposed over footings may be used in computing the moment of stability due to dead load.

(b) When the total resisting force due to friction is insufficient to prevent sliding, the building or other structure shall be anchored to withstand the excess sliding force without exceeding the allowable stresses for the materials used. Anchors provided to resist overturning moment may also be considered as providing resistance to sliding.

5-10. Stresses During Erection.-Provision shall be made for wind stress during erection of the building or other structure.

\section{SECTION 6. EARTHQUAKE LOADS-GENERAL}

6-1. Minimum Lateral Load.-Every building or other structure, except a farm building or like structure, shall be designed and constructed to withstand a static lateral load from any horizontal direction at least equal to 5 percent of the dead load.

6-2. Combined Stresses.-For combined stresses due to the lateral load specified in Section 6-1 together with dead, live, and snow loads, the allowable stresses may be increased 50 percent provided the section thus found is at least as strong as that required for dead, live, and snow loads alone. The section thus found shall also be compared with that found for the combination of wind, dead, live, and snow loads, and that section used which provides the greater strength.

6-3. Horizontal Torsional Moments. - The vertical structural units of a building or other structure that resist lateral load shall be so arranged that, in any horizontal plane, their center of rigidity will be coincident with the center of gravity of the dead loads of the building or other structure, or proper provision shall be made for any resulting torsional moment in the building or other structure. 
6-4. Distribution of Horizontal Shear.-The total shear at any level due to the lateral load shall be assumed to be distributed to the vertical resisting units at that level in proportion to their rigidities, except as the deformation of horizontal distributing elements may modify the distribution.

6-5. Special Requirements.-Every parapet wall shall be designed and constructed to withstand a normal lateral force of 50 percent of its weight. Every tank tower, tank, and masonry chimney shall be designed and constructed to withstand a lateral force from any direction equal to 10 percent of its dead and vertical live loads.

\section{SECTION 7. EARTHQUAKE LOADS-MAJOR EARTHQUAKES}

Note.-It is recommended that these provisions be included in building ordinances in those communities that have experienced earthquakes of major or near-major intensity, say of intensity of VII or over in the Rossi-Forel scale.

\section{7-1. Minimum Lateral Load.}

(a) Every building or other structure shall be designed and constructed to withstand a minimum static lateral load, acting from any horizontal direction, as given by the formula

in which

$$
F=C W
$$

$F=$ Horizontal lateral load in pounds

$C=\mathrm{A}$ numerical coefficient as given hereafter

$W=$ The total dead load in pounds at and above the plane or elevation under consideration, except that for buildings used for storage. $W$ shall equal the total dead load plus 50 percent of the live load.

(b) The coefficient $C$ shall have the following values ( $F$ being assumed to act from any direction), provided that for buildings not over 100 feet in height in which the ratio of height to least horizontal dimension is not over $1.5, C$ shall be taken as 0.10 for each story.

Values of $C$ for parts of buildings or other structures

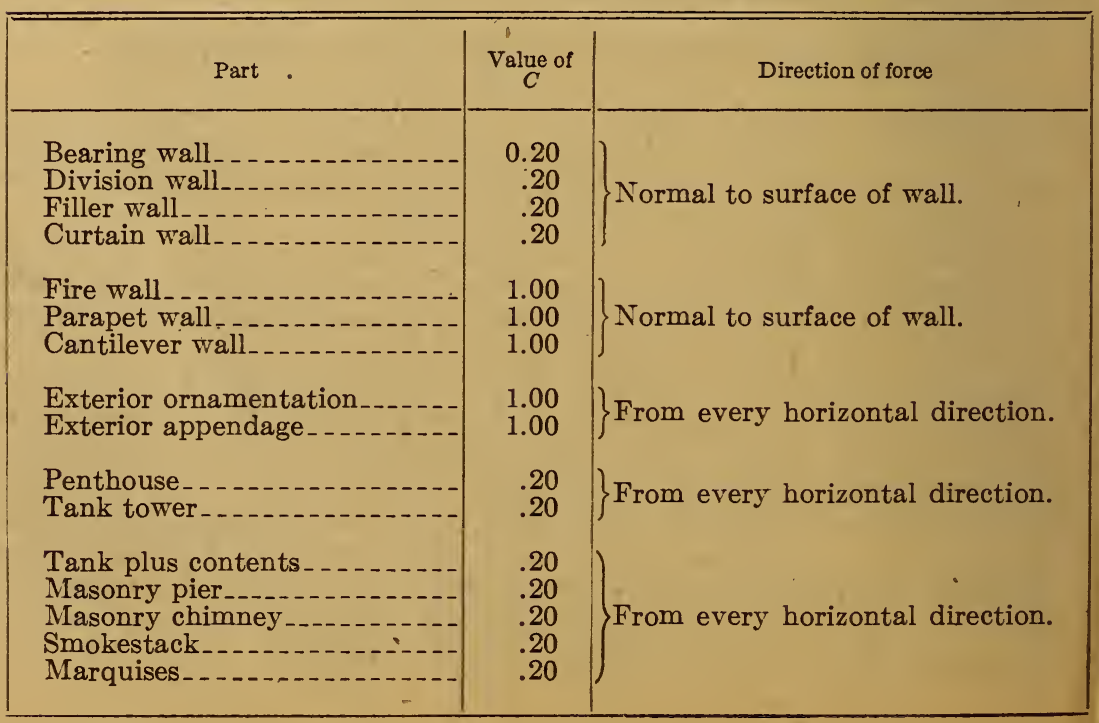


7-2. Resistance of Skeleton Frame.-In every building having a skeleton frame, such frame shall be designed and constructed to withstand not less than 20 percent of the force specified for the building itself, without assistance from any walls or floors. By skeleton frame is meant a framework consisting of columns, girders, beams, and similar members supporting and transmitting all loads to the foundations.

7-3. Combined Stresses.-For combined stresses due to the lateral load specified in Section 7-1, Minimum Lateral Load, in combination with dead, live, and snow loads, the allowable stresses may be increased 50 percent provided the section thus found is at least as strong as that required for dead, live, and snow loads alone. The section thus found shall also be compared with that found for the combination of wind, dead, live, and snow loads, and that section used which provides the greater strength.

For members with stresses due only to the lateral load specified in Section 7-1, Minimum Lateral Load, the allowable stresses for the materials used may be increased not more- than $66^{2 / 3}$ percent.

7-4. Horizontal Torsional Moments.-Those vertical structural units of the building or other structure which resist the horizontal force shall be so arranged that in any horizontal plane the center of rigidity of such resisting structural units will be coincident with the center of gravity of the vertical loads of the building or other structure, or else proper provision shall be made for the resulting torsional moment in the building or other structure.

7-5. Distribution of Horizontal Shear.-The total horizontal shear at any level shall be assumed to be distributed to the various resisting units at that level in proportion to their rigidities, except as the deformation of the horizontal distributing elements may modify the distribution.

7-6. Connections. - Such connections of members as resist the moments and shears of the specified horizontal force shall also be made capable of resisting moments and shears due to vertical loads in proportion to their relative stiffness.

7-7. Utilization of Permanent Structural Elements.-Reinforcedconcrete or masonry walls and all other permanent structural elements capable of providing resistance shall be assumed to act integrally with the structural frames in resisting the shears and moments due to the specified horizontal force, unless specifically designed and constructed to act independently.

\section{APPENDIX}

This Appendix consists of explanatory and supplementary material designed to assist local building code committees and building officials in applying the recommended code requirements. It. is not a part of American Standard Building Code Requirements for Minimum Design Loads in Buildings and Other Structures-A58.1; but is provided as background material for users of the standard. In some cases it will be necessary to adjust specific values in the standard to local conditions; in others, a considerable amount of detailed information is needed to put the general provisions into effect. This Appendix provides a place for supplying material that can be used in these situations and also is intended to create a.better understanding of the 
recommended requirements through brief explanations of the reasoning employed in arriving at them.

The subdivisions of the Appendix are numbered to correspond with the section numbers in the Code requirements. Since it is not necessary to have Appendix matter for every section in the Code, there are gaps in the numbering in the Appendix.

General.- Since 1924, when a report of the Department of Commerce Building Code Committee entitled "Minimum Live Loads Allowable for Use in Design of Buildings" was published by the National Bureau of Standards, the recommendations contained in that document have been widely used in revision of local building codes and have been quoted in many textbooks. The recommendations made at that time were based on a study of data obtained from many sources and represented the considered judgment of experienced architects and engineers.

At the present time, a continuation of development of building code recommendations is being carried on by various sectional committees operating under the procedure of the American Standards Association, with the Building Code Correlating Committee providing the necessary guidance and correlation. The Sectional Committee on Building Code Requirements for Minimum Design Loads in Buildings-A58 is one of these sectional committees. It has considered the work of the previous committee which brought out the 1924 report and has taken into account facts developed in later investigations so as to provide requirements suitable for use under present conditions. It has also endeavored to cover a wider field than in the earlier report, and has provided information on the various kinds of loads to which structures may be subjected. Loads have been construed to include weight of materials and equipment, weight of occupants and of movable contents, wind pressures, and earthquake forces. Some of these loads will be the same regardless of the location of the structure and others will vary with local conditions. Information is provided to make it possible to deal with the whole range of circumstances that may have to be taken into account.

2-1. Weights of Materials and Constructions.-Values for weights of different materials and constructions are based on a schedule prepared in the Office of the Supervising Architect, Public Buildings Administration, Federal Works Agency. They have been reviewed by the National Bureau of Standards and by a number of other agencies with respect to particular items on which the agency had information.

To establish uniform practice among designers it is desirable to present a list of materials generally used in building construction together with their proper weights. Many building codes prescribe the minimum weights for only a few building materials and in other instances no guide whatsoever is furnished on this subject. In some cases the codes are so drawn up as to leave the question of what weights to use to the discretion of the building official without pro- 
viding him with any authoritative guide. This practice, as well as the use of incomplete lists, has been subjected to much criticism. The solution chosen has been to present an exténded list in this Appendix which will be useful to the designer and official alike. However, special cases will unavoidably arise, and so authority is granted to the building official to deal with these.

For ease of computation, most, values are given in terms of weight per square foot of given thicknesś. Cubic-foot values consistent with the square-foot values are also presented in somes cases.

TABLE 1.-Minimum design dead loads a



WALLS

4-inch clay brick, high absorption

4 -inch clay brick, medium absorption

4-inch clay brick, low absorption

4 -inch sand-lime brick

4 -inch concrete brick, heavy aggregate... 46

4-inch concrete brick, light aggregate

8-inch clay brick, high absorption

8-inch clay brick, medium absorption

8-inch clay brick, low absorption _._. 89

8 -inch sand-lime brick

8-inch concrete brick, heavy aggregate. 89

8 -inch concrete brick, light aggregate

$121 / 2$-inch clay brick, high absorption

$121 / 2$-inch clay brick, medium absorption

$121{ }^{\prime}$-inch clay brick, low absorption

$121 / 2$-inch sand-lime brick

$121 / 2$-inch concrete brick, heavy aggregate

$121 / 2$-inch concrete brick, light aggregate $\ldots$

17 -inch clay brick, high absorption

17-inch clay brick, medium absorption

17-inch clay brick, low absorption

17-inch sand-lime brick

17-inch concrete brick, heavy aggregate

17-inch concrete brick, light aggregate-1

22-inch clay brick, high absorption

22-inch clay brick, medium absorption.

22-inch clay brick, low absorption

22-inch sand-lime brick

22-inch concrete brick, heavy aggregate... 216

22-inch concrete brick, light aggregate

4-inch brick, 4-inch load-bearing structural clay tile backing

4-inch brick, 8-inch load-bearing structural clay tile backing

9-inch brick, 4-inch load-bearing structural clay tile backing

8-inch load-bearing structural clay tile $\ldots \ldots$

12-inch load-bearing structural clay tile... 58

8 -inch concrete block, heavy aggregate

12-inch concrete block, heavy aggregate

8-inch concrete block, light aggregate...

12-inch concrete block, light aggregate

2 -inch furring tile, one side of masonry wall, add to above figures...... 12

- Weights of masonry include mortar but not plaster. For plaster, add $5 \mathrm{lb} / \mathrm{ft}^{2}$ for each face plastered. Values given represent averages. In some cases there is a considerable range of weight for the same construction. For such ranges, see pages 16 and 17. 
TABLE 1.-Minimum design dead loads ${ }^{\mathrm{a}}$-Continued!

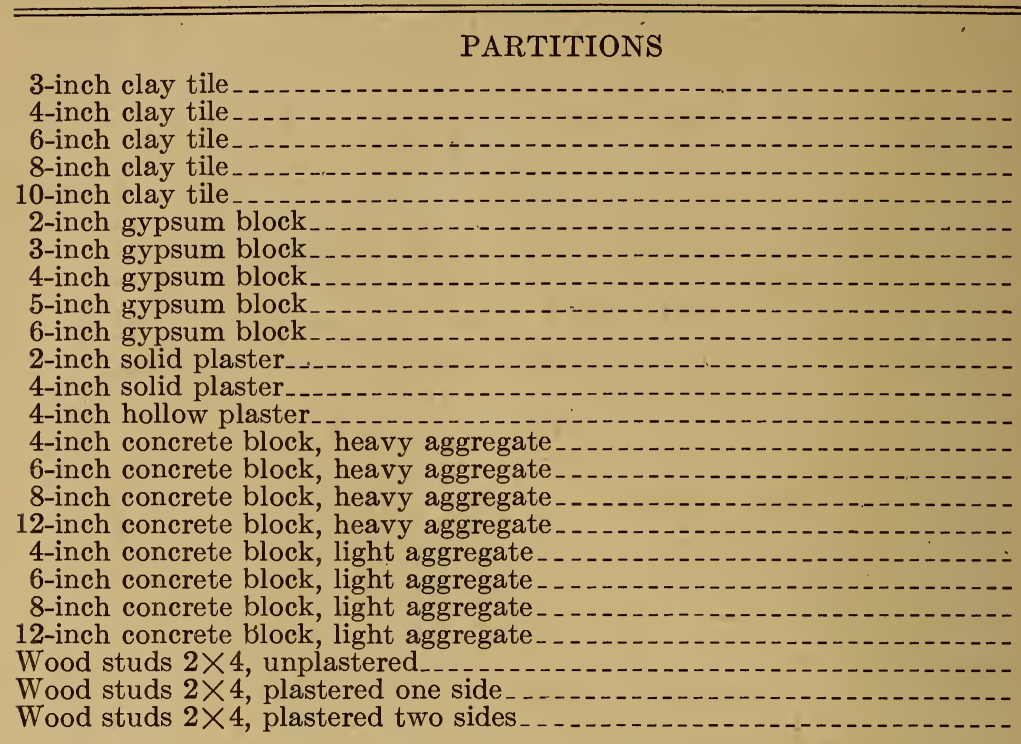

\section{GLASS-BLOCK MASONRY}

4-inch glass-block walls and partitions

\section{SPLIT FURRING TILE}

$1 \frac{1}{2}$-inch

2-inch

\section{CONCRETE SLABS}

Concrete, reinforced-stone, per inch

Concrete, reinforced-cinder, per inch

Concrete, reinforced, lightweight, per inch

Concrete, plain stone, per inch

Concrete, plain cinder, per inch

Concrete, plain, lightweight, per inch

a See footnote on page 11. 
TABLE 1.-Minimum design dead loads a-Continued

RIBBED SLABS

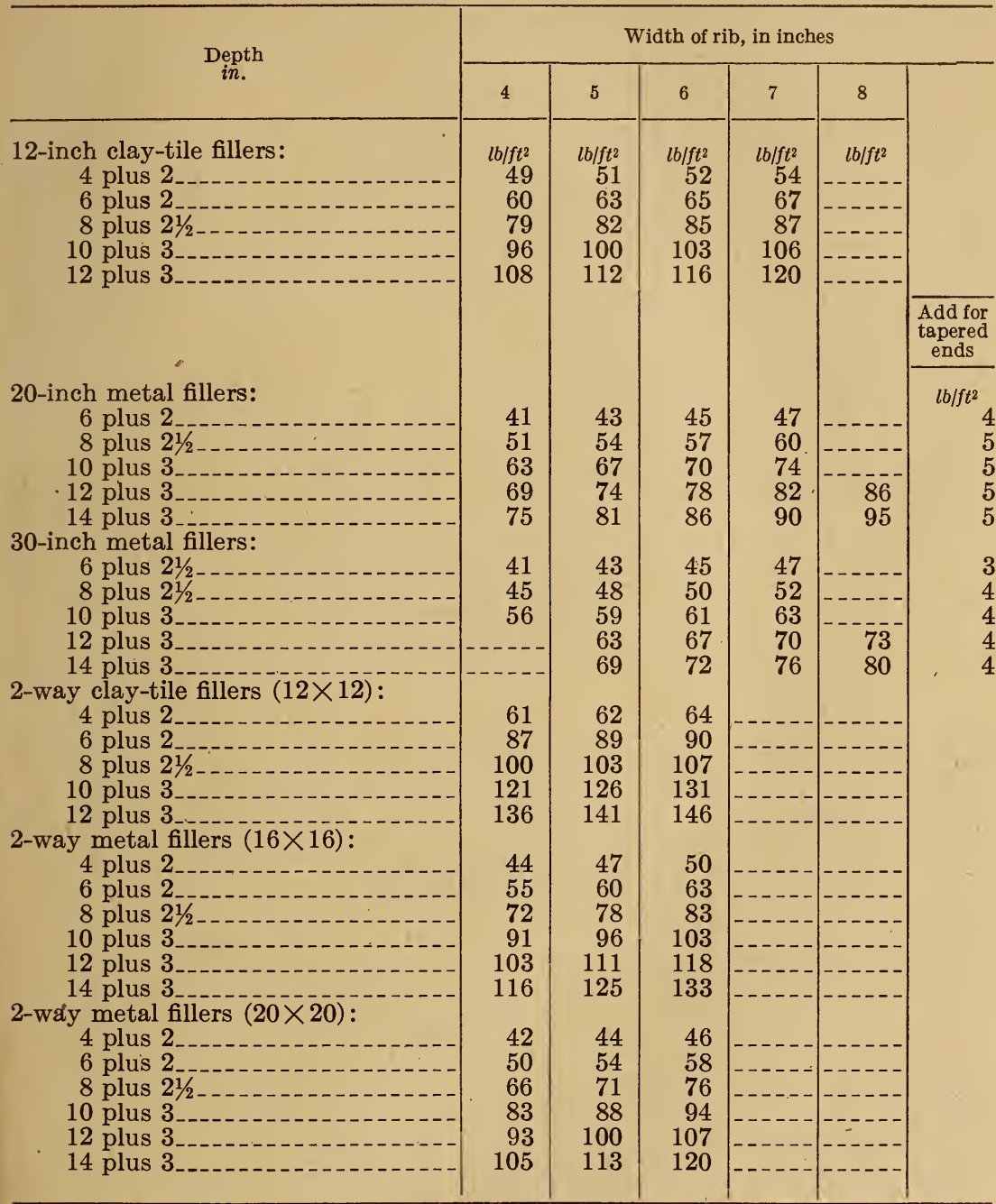

- See footnote on page 11. 
TABLE 1.-Minimum design dead loads a-Continued

FLOOR FINISH AND FILL

Double $7 / 8$ wood on sleepers, light-concrete fill

Do

Double $7 / 8$ wood on sleepers, stone-concrete fill

Do $7 / 8$ wood on sleepers, light-concrete fill

Single $7 / 8$ wood on sleepers, light-concrete fill

Single $7 / 8$ wood on sleepers, stone-concrete fill-

3-inch wood block on mastic, no fill-

1 -inch cement fin. on stone-concrete fill

1 -inch terrazzo on stone-concrete fill.

Clay tile on stone-concrete fill

Marble and mortar on stone-concrete fill

Linoleum on stone-concrete fill.

Linoleum on light-concrete fill

Do....

\begin{tabular}{|c|c}
$\begin{array}{c}\text { Finish } \\
\text { floor to } \\
\text { top slab, } \\
\text { in. }\end{array}$ & lb/ft2 \\
\hline & \\
\hline 4 & 19 \\
5 & 26 \\
4 & 28 \\
5 & 40 \\
4 & 23 \\
5 & 30 \\
4 & 38 \\
5 & 50 \\
3 & 10 \\
4 & 40 \\
4 & 48 \\
4 & 48 \\
4 & 48 \\
4 & 50 \\
4 & 46 \\
5 & 58 \\
4 & 27 \\
5 & 34 \\
\hline
\end{tabular}

\section{FLOOR FINISH}

$1 \frac{1}{2}$-inch asphalt mastic flooring

3 -inch wood block on 1/2-inch mortar base

Solid flat tile on 1-inch mortar base

1 -inch terrazzo, 2-inch stone concrete

\begin{tabular}{|r|r}
$\begin{array}{r}\text { Thick- } \\
\text { ness, in. }\end{array}$ & $1 \mathrm{lb} / \mathrm{ft}^{2}$ \\
\hline & \\
$11 / 2$ & 18 \\
$31 / 2$ & 16 \\
2 & 23 \\
$21 / 2$ & 30 \\
3 & 38 \\
\hline
\end{tabular}

\section{WATERPROOFING}

\begin{tabular}{l|r|r}
\hline Five-ply membrane & $1 / 2$ & 5 \\
Five-ply membrane, mortar, stone concrete... & 55 \\
2-inch split tile, 3-inch stone concrete & 5 & 45 \\
\hline
\end{tabular}

FLOOR FILL

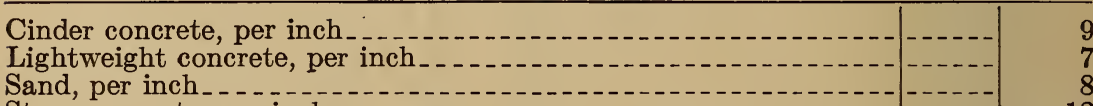

Stone concrete, per inch 12

\section{WOOD-JOIST FLOORS (NO PLASTER) DOUBLE WOOD FLOOR}

\begin{tabular}{|c|c|c|}
\hline & $\begin{array}{l}\text { 12-inch } \\
\text { spacing }\end{array}$ & $\begin{array}{l}\text { 16-inch } \\
\text { spacing }\end{array}$ \\
\hline 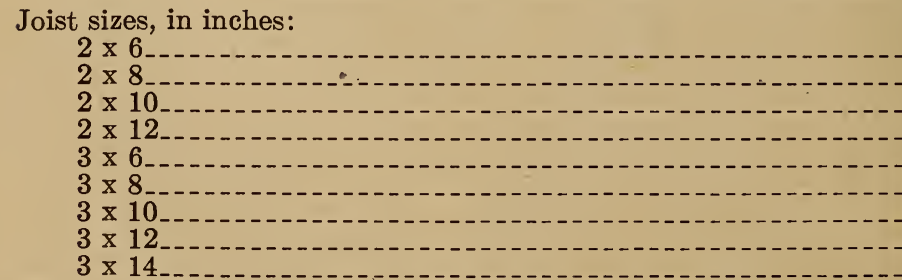 & $\begin{array}{r}l b / f t^{2} \\
6 \\
6 \\
7 \\
8 \\
7 \\
8 \\
9 \\
11 \\
12\end{array}$ & $\begin{array}{r}l b / f t^{2} \\
5 \\
6 \\
6 \\
7 \\
6 \\
7 \\
8 \\
9 \\
10\end{array}$ \\
\hline
\end{tabular}

s See footnote on page 11 . 
TABLE 1.--Minimum design dead loads a-Continued

CEILINGS lblft

Plaster on tile or concrete

Suspended metal lath and gypsum plaster.

Suspended metal lath and cement plaster. 15

Plaster on wooden lath

\section{ROOF COVERINGS}

Asbestos shingles

$/ f t^{2}$

Asphalt shingles

Copper or tin

Corrugated iron

Clay tile (for mortar add $10 \mathrm{lb}$ ):

2-inch book tile

3-inch book tile

Roman

Spanish - -

Ludowici....

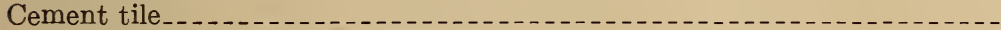

Composition:

Three-ply ready roofing.

Four-ply felt and gravel

Five-ply felt and gravel

Sheathing, per inch thickness

Slate, $3 / 16$-inch

Slate, $1 / 4$-inch

Skylight, metal frame, $3 / 8$-inch wire glass

Wood shingles..............

Cast-stone masonry (cement, stone, sand)

Concrete, plain:

Stone (including gravel)

Slag

Cinder

Haydite (burned-clay aggregate)

Expanded-slag aggregate

Concrete, reinforced:

Stone (including gravel)

Slag

Cinder

Masonry, brick:

Hard (low absorption)

Medium (medium absorption)

Soft (high absorption)

Limestone, oolitic

Marble

144

Sandstone

Voids filled

Voids unfilled

Timber, seasoned:

Ash, commercial white

Cypress, southern

Fir, Douglas, coast region,

Oak, commercial reds and whites

Pine, southern yellow

Redwood . .

Spruce, red, white, and Sitka.

-See footnote on page 11. 
Range in Weights.- Some constructions for which a single figure is given actually have a considerable range in weight. The average figure given is suitable for general use; but when there is reason to suspect a considerable deviation from this, the actual weight should be determined.

Examples of the range in weight that have been found for some constructions follow. It will be noted that there is a difference of over 25 percent in some cases.

Range in weight of masonry construction

\begin{tabular}{c|c|c|c}
\hline Construction & Unplastered & $\begin{array}{c}\text { One side plas- } \\
\text { tered }\end{array}$ & $\begin{array}{c}\text { Both sides } \\
\text { plastered }\end{array}$ \\
\hline
\end{tabular}

WALLS

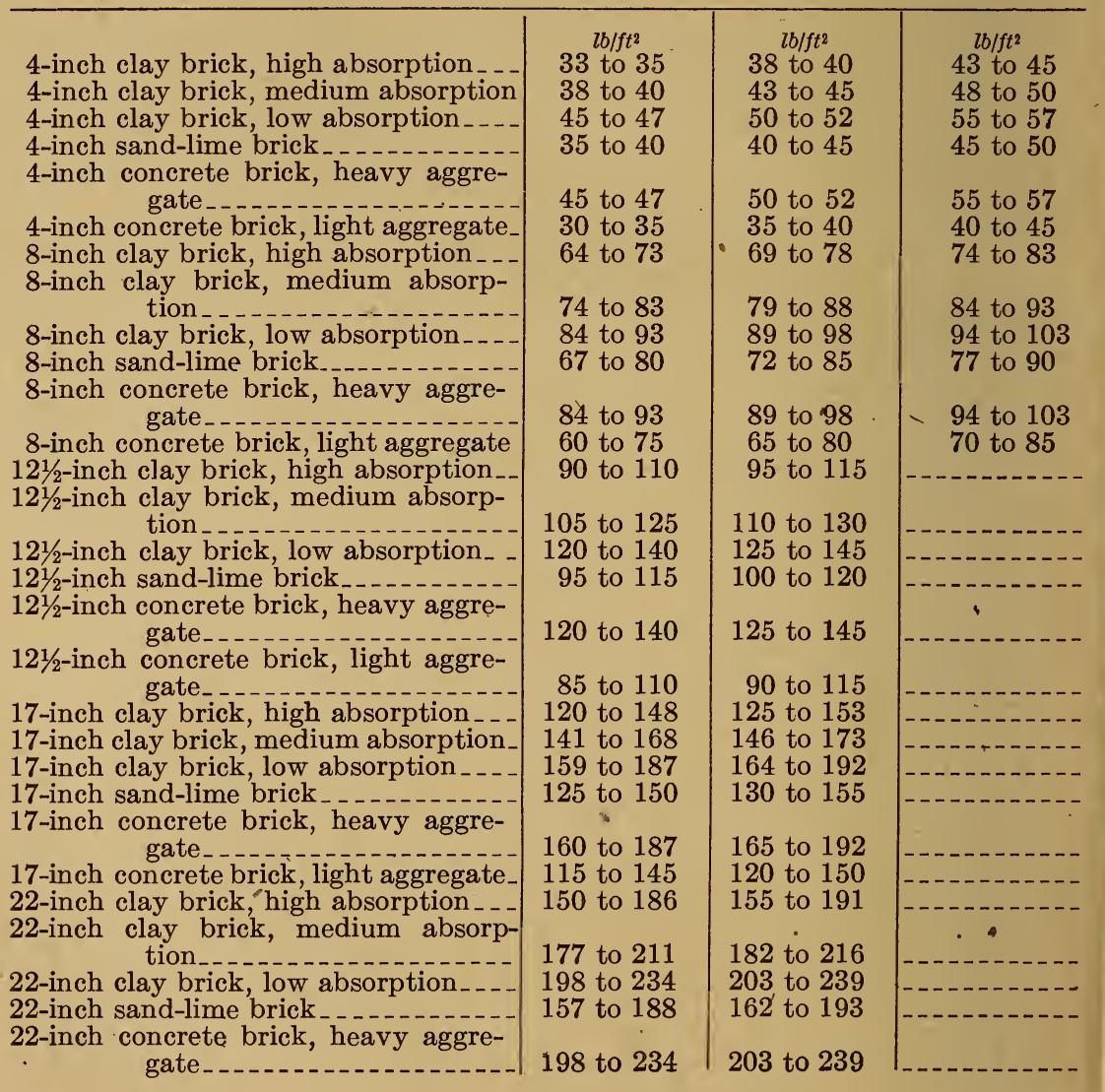


Range in weight of masonry construction-Continued

\begin{tabular}{l|l|l|l}
\hline \hline$\quad$ Construction & Unplastered & $\begin{array}{c}\text { One side plas- } \\
\text { tered }\end{array}$ & $\begin{array}{c}\text { Both sides } \\
\text { plastered }\end{array}$ \\
\hline
\end{tabular}

WALLS-Continued

\begin{tabular}{|c|c|c|c|}
\hline & $l b / f t^{2}$ & $l b / f t^{2}$ & $l b / f t^{2}$ \\
\hline $\begin{array}{l}\text { 22-inch concrete brick, light aggregate } \\
\text { 8-inch load-bearing structural clay }\end{array}$ & 140 to 180 & 145 to 185 & \\
\hline 12-inch load-bearing structural clay & 37 to 46 & 42 to 51 & 47 to 56 \\
\hline $\begin{array}{l}\text { 12-incn load-oearing structural ciay } \\
\text { tile }\end{array}$ & 50 to 65 & 55 to 70 & 60 to 75 \\
\hline $\begin{array}{l}\text { 8-inch concrete block, heavy aggre- } \\
\text { gate }\end{array}$ & 50 to 60 & 55 to 65 & 60 to 70 \\
\hline $\begin{array}{l}\text { 12-inch concrete block, heavy aggre- } \\
\text { gate }\end{array}$ & 75 to 95 & 80 to 100 & 85 to 105 \\
\hline $\begin{array}{l}\text { 8-inch concrete block, light aggregate } \\
12 \text {-inch concrete block, light aggregate }\end{array}$ & $\begin{array}{l}30 \text { to } 43 \\
45 \text { to } 65\end{array}$ & $\begin{array}{l}35 \text { to } 48 \\
50 \text { to } 70\end{array}$ & $\begin{array}{l}40 \text { to } 53 \\
55 \text { to } 75\end{array}$ \\
\hline
\end{tabular}

PAARTITIONS

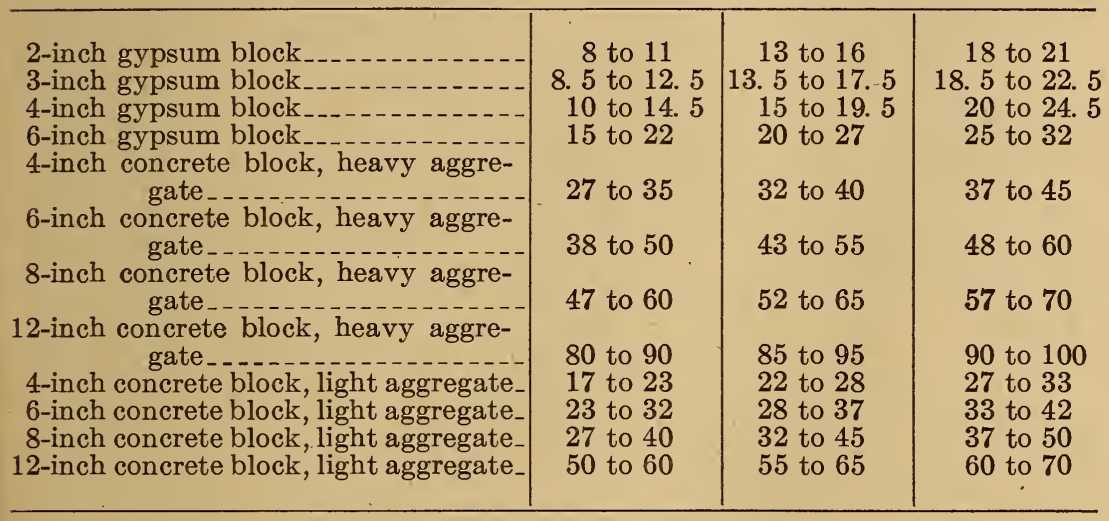

GLASS-BLOCK MASONRY

\begin{tabular}{r|r|r|}
\hline $\begin{array}{r}\text { 4-inch glass-block walls and parti- } \\
\text { tions }\end{array}$ & 17 to 19 & \\
\hline
\end{tabular}

3-1 (a) Uniformly Distributed Floor Loads.-A selected list of occupancies and uses more commonly encountered is given in Section 3-1 (a) and the building official is given authority to pass on occupancies not mentioned. Table 2 below is offered as a guide in the exercise of such authority. 
TABLE 2.-Minimum uniformly distributed live loads

\begin{tabular}{|c|c|c|c|}
\hline & & & $l b / f t^{2}$ \\
\hline (machine space) & 00 & Libraries: & \\
\hline Amph & & ling rooms & 60 \\
\hline & 60 & Corrido & e 100 \\
\hline $\begin{array}{r}\text { Mo } \\
\text { musem }\end{array}$ & 100 & Stacks & (b) \\
\hline musen & $=100$ & Manufacturing: & \\
\hline & 150 & Ice & 30 \\
\hline Attic: & & Stockroom (see Storage). & \\
\hline & 25 & Marquis & g 60 \\
\hline Stor & e 80 & Morgue & 12 \\
\hline 3akery & 150 & Office buildings: & \\
\hline 3alcon & & Files (see File room). & \\
\hline a casta) & 100 & Business machine equip- & \\
\hline ts) & 60 & ment & a 10 \\
\hline eats) & 100 & Penal institutions: & \\
\hline -...-. & e 100 & $\mathrm{rS}_{-}$. & \\
\hline & a 300 & $-\ldots$ & 100 \\
\hline .. & 100 & $\mathrm{pu}$ & 100 \\
\hline & 25 & Printin & \\
\hline furred.- & 10 & g roc & \\
\hline Col & & $\mathrm{oms}$ & 100 \\
\hline & b 250 & $P$ & 150 \\
\hline & & & \\
\hline & 150 & Public & 10 \\
\hline & 250 & & \\
\hline Dormitori & & ay (see Gar & \\
\hline & 40 & rian (see Side- & \\
\hline $\mathrm{N}$ & 80 & $3-10(\mathrm{~b})$; also & \\
\hline Drill $\mathrm{r}$ & 125 & Corridors in sec. $3-1$.) & \\
\hline & & $\mathrm{e}(\mathrm{see} \mathrm{H}$ & \\
\hline $\mathrm{m}_{-}$ & \& 150 & Rest & 60 \\
\hline Fan & a 150 & Reviewing stands and grand- & \\
\hline File $\mathrm{r}$ & & & ${ }^{\mathrm{i}} 100$ \\
\hline & e 80 & 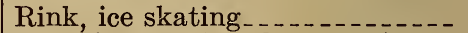 & 25 \\
\hline & e 125 & ig. 1 and sec. $3-9)$. & \\
\hline -....... & e 150 & . & 10 \\
\hline ......... & 100 & & \\
\hline & $\therefore 600$ & & 12 \\
\hline framed. & 400 & $\mathrm{H}$ & 25 \\
\hline Grandstands (see Reviewing & & grain & e 30 ( \\
\hline $\begin{array}{l}\text { stands) } \\
\text { Garages: }\end{array}$ & & Teleph & \\
\hline Cars, with load, less than & & rooms_... & \\
\hline 3 tons & $\neq 100$ & Grid-iron floor or fly gal- & \\
\hline Trucks, with load, 3 to 10 & & lery- & \\
\hline above 10 & 150 & 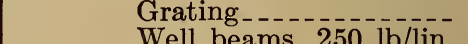 & \\
\hline with load, above 10 & 00 & $\begin{array}{l}\text { Well beams, } 250 \mathrm{lb} / \mathrm{lin} \text {. } \\
\text { ft per pair. }\end{array}$ & \\
\hline & 0 & Header bean & \\
\hline & 00 & $\mathrm{lb} / \mathrm{lin}$. ft. & \\
\hline & \& 150 & il, 250 lb/lin. ft. & \\
\hline & 100 & ection room & 10 \\
\hline & a 150 & Toilet $\mathrm{r}$ & \\
\hline ific_.... & 100 & Transformer rooms. & a 200 \\
\hline dries & \& 150 & 1tts in offices & e 25 \\
\hline
\end{tabular}

- Use equipment when greater.

b Book stacks $20 \mathrm{lb} / \mathrm{ft}^{3}$.

- As required by railroad company.

d Paper storage $50 \mathrm{lb} / \mathrm{ft}$ of clear story height.

- Increase when occupancy exceeds this amount.

Also subject to maximum wheel concentrations.

g Minimum uplift of $20 \mathrm{lb} / \mathrm{ft}^{2}$ with no downward live load.

h Plus $150 \mathrm{lb}$ for trucks.

i For detailed recommendations, see American Standard Specifications for Portable Steel and Wood Grandstands, Z20.1-1941, or latest revision thereof. 
For purposes of estimating live loads caused by accumulations of various materials, a list of weights is given in table 3 . Some of the items may also be useful in connection with estimation of dead loads.

TABLE 3.-Minimum design loads for materials

Bituminous products:

Asphaltum . . . .......-

Graphite....

Paraffine.......

Petroleum, crude......

Petroleum, refined.....-

Petroleum, benzine....-

Petroleum, gasoline...-.

Pitch

Tar

Brass

Bronze..........

Cement, portland, loose

Cement, portland, set......-

Cinders, dry, in bulk

Coal, anthracite, piled

Coal, bituminous, piled .....-

Coal, lignite, piled

Coal, peat, dry, piled

Charcoal

Copper

Cork, compressed

Earth (not submerged):

Clay, dry

Clay, damp.-.

Clay and gravel, dry

Silt, moist, loose

Silt, moist, packed...-..

Silt, flowing---_-_----

Sand and gravel, dry, loose

Sand and gravel, dry, packed.....

Sand and gravel, wet..-.-

Earth (submerged):

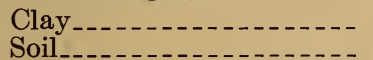

River mud.

\begin{tabular}{|c|c|c|}
\hline$l b / f t^{3}$ & & $l b / f t^{3}$ \\
\hline & Earth (submerged)-Continued & \\
\hline $\begin{array}{r}81 \\
135\end{array}$ & Sand or gravel & 60 \\
\hline 135 & Sand or gravel, and clay_- & 65 \\
\hline 56 & Gold, solid _. & 1,205 \\
\hline 55 & Gold bars, stacked. & 1,133 \\
\hline 50 & Gold coin in bags & 1,084 \\
\hline 46 & Gypsum, loose & 65 \\
\hline 42 & Ice & 57.2 \\
\hline 69 & Iron, cast_- & 450 \\
\hline 75 & Iron, wrought.- & 480 \\
\hline 526 & Lead & 710 \\
\hline 552 & Lime, hydrated, loose & 32 \\
\hline 70 & Lime, hydrated, compacted - - & 45 \\
\hline 125 & Mortar, hardened: & \\
\hline 45 & $\begin{array}{l}\text { Cement_. } \\
\text { Lime }\end{array}$ & 130 \\
\hline $\begin{array}{l}52 \\
47\end{array}$ & Riprap (not submerged): & \\
\hline 47 & Limestone & 83 \\
\hline 23 & Sandstone & 90 \\
\hline 12 & Slag, bank & 70 \\
\hline 556 & Slag, bank screenings & 108 \\
\hline 14.4 & Slag, machine & 96 \\
\hline & $\begin{array}{l}\text { Slag, sand } \\
\text { Silver, solid }\end{array}$ & $\begin{array}{r}52 \\
656\end{array}$ \\
\hline 63 & Silver bars, stacked & 590 \\
\hline 110 & Silver coin in bags & 590 \\
\hline 100 & Slate & 172 \\
\hline 96 & Steel, cold-drawn_. & 489 \\
\hline 108 & Stone, quarried, piled: & \\
\hline 100 & Basalt, granite, gneiss---- & 96 \\
\hline & Limestone, marble, quartz & 95 \\
\hline 110 & Shale & 92 \\
\hline 20 & Greenstone, hornblende & 107 \\
\hline & Tin & 459 \\
\hline 80 & Water, fresh. & 62.4 \\
\hline 70 & Wa & 64 \\
\hline 90 & Zinc, rolled, sheet_. & 449 \\
\hline
\end{tabular}

3-6. Reduction of Live Load.-The proposed live-load-reduction formula in Section 3-6 (b) differs from conventional treatment but is believed to offer a more logical approach than is found in most building codes. The provisions are based upon a consideration of data available on distribution of loads in different occupancies, and more particularly a survey made by the Public Buildings Administration covering loads in a number of Federal buildings. The results of this survey are to be published in the Proceedings of the American Society of Civil Engineers.

The system proposed for live-load reduction consists essentially of a basic live load equal to the maximum to be allowed on any panel and a rapid reduction to a minimum load based upon the relation of live and dead loads in such a manner that overstress on any member, due to full basic load throughout the structure, cannot exceed a pre- 
determined value. Moreover, the system should be such that only a very small portion of the structure will be overstressed by the probable actual live loads.

It is proposed that:

1. The basic live load shall be the maximum average live load intended to be allowed on any panel.

2. The basic live load may be reduced for the design of any member at the rate of 0.08 percent per square foot of area supported by the member.

3. The reduction shall exceed neither $R$ percent as determined by the following formula nor 60 percent:

in which

$$
R=100 \times \frac{D+L}{4.33 L}
$$

$R=$ reduction, in percent

$D=$ dead load per square foot of area supported by the member

$L=$ design live load per square foot of area supported by the member.

The maximum reduction is such that if a member supports an area large enough to allow the maximum reduction, and if the member is loaded with the full design live load, the overstress will not exceed 30 percent. The formula is derived as follows:

Let

$D$ and $L$ have the values given above

$K=$ proportional reduction

Then

$R=\%$ reduction $=100 K$.

$$
\begin{aligned}
L+D & =1.3[D+(1-K) L] \\
L+D & =1.3 D+1.3 L-1.3 K L \\
1.3 K L & =0.3 D+0.3 L \\
K & =\frac{L+D}{4.33 L} \\
R & =100 \times \frac{L+D}{4.33 L} .
\end{aligned}
$$

It has been found by comparing the results of this formula with actual load conditions in a number of buildings that only a small portion of the structure would be overstressed.

The proposed system is, of course, based on the assumption, as any such system must be, that excessive overloading will be prevented through posting of allowable loads and adequate inspection. The system when so safeguarded should provide a suitable basis for design of buildings without:

(1) The incorporation of so much unused strength as heretofore;

(2) Significant overstress in members from probable loadings;

(3) Danger of structural failure in the remote contingency of full basic loading on the entire area supported by any member. 
Since public-assembly occupancies, such as theaters, must be assumed to be fully occupied under normal conditions, any reduction would be unwarranted. An exception has therefore been made in the case of these occupancies.

In the case of occupancies involving relatively heavy basic live loads, such as storage buildings, several adjacent floor panels may be fully loaded. However, data obtained in actual buildings indicate that rarely is any story loaded with an average actual live load of more than 80 percent of the average rated live load. It appears that the basic live load should be unreduced for the floor-and-beam design but that it could be reduced a flat 20 percent for the design of columns. Accordingly, this principle has been incorporated in the recommended code requirement.

3-9. Roof Loads (including snow loads).-Figure 1 showing isopleths connecting points of equal snow load is based upon a map prepared by the United States Weather Bureau. Values for any particular location not on an isopleth may be found by interpolating along the shortest. line through the location between isopleths or between an isopleth and point having different values. The values shown are probably conservative since they are based upon maximum depth of snow on the ground rather than on roofs.

The pressures shown on this map are based upon the maximum undrifted snow depth on the ground as reported by first order Weather Bureau stations during the period from the beginning of record to December 1938, inclusive, and on the assumption that 6.5 inches of snow have the same water content as 1 inch of rain. This assumed density may vary in different localities.

Isopleths have been omitted in the region between the Pacific Coastal Section and Longitude $117^{\circ} \mathrm{W}$. due to the irregular distributions associated with rugged terrain.

3-11. Load Tests.-A specific method of test for completed construction has not been given in the requirements, since it may be found advisable to vary the procedure according to conditions. Some codes require the construction to sustain a superimposed load equal to twice the design live load for 24 hours without evidence of damage. Other provide for a superimposed test load equal to one-half of the dead load plus one and one-half times the live load, with the evident intention of increasing the stresses in the affected members by a definite percentage of the allowable stress. Recovery of at least three-quarters of the maximum deflection within 24 hours after the load is removed is a common requirement. Concrete and masonry construction should be at least 60 days old when tested.

5-1. Minimum Design Wind Pressures.-The requirements in Section 5, Wind Loads, are intended for more or less average conditions. There is considerable variation in wind-velocity pressures in different parts of the country, as will be seen by reference to figure 2 . This map has been prepared at the National Bureau of Standards, from data obtained from the United States Weather Bureau. Local building code committees should consult this map and also obtain any other available facts on conditions in their own areas. With this information in hand, any necessary adjustments in requirements can be made. 


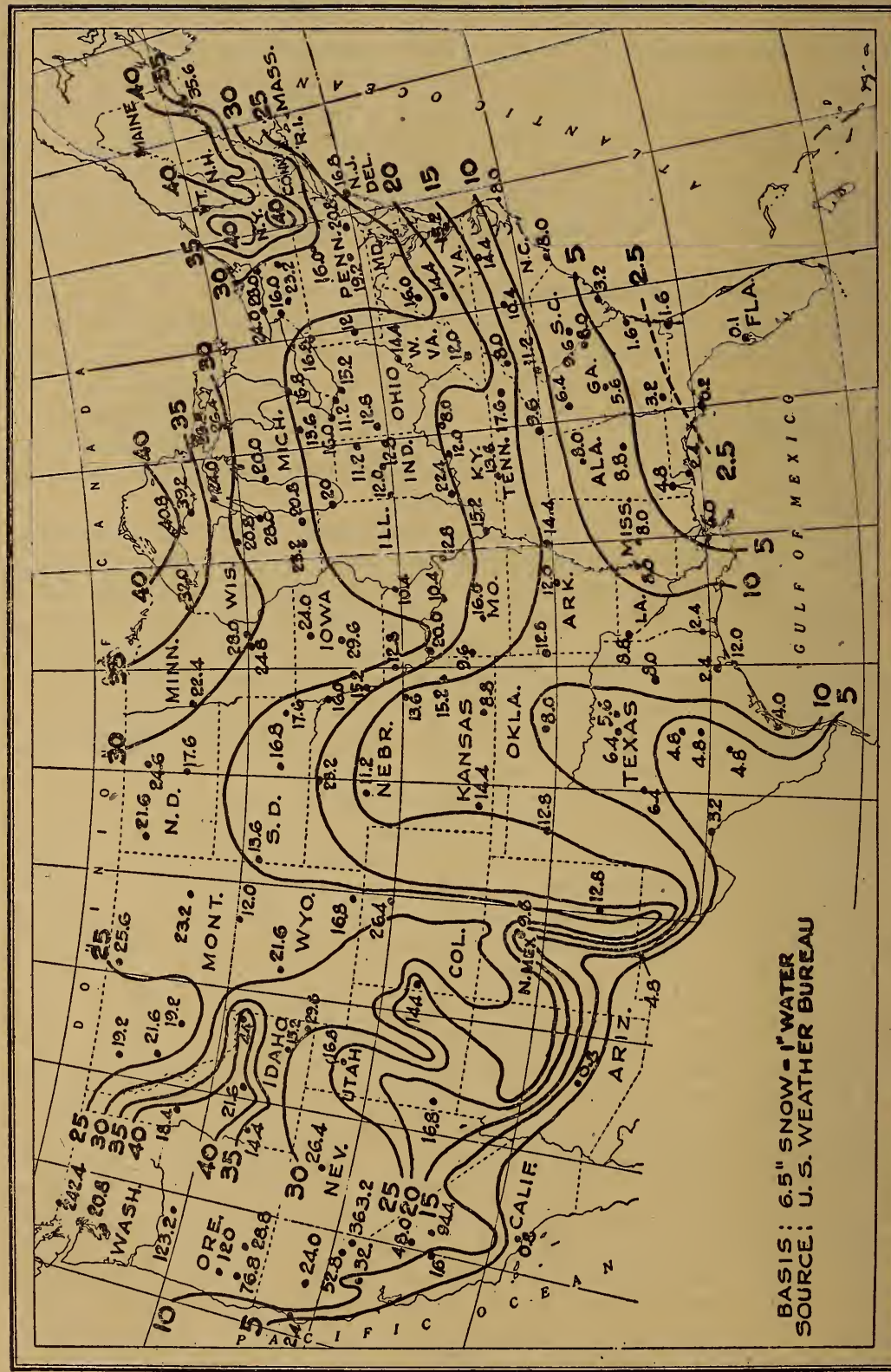

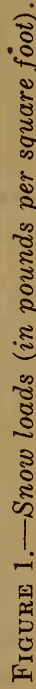


The design wind load, which should not be confused with the velocity pressure shown on figure 2 , is the product of the velocity pressure and a shape coefficient determined by the geometrical form of the structure. The velocity pressure is influenced by geographical location, height above ground, and exposure. It is the computed pressure on a square foot of surface perpendicular to the wind, representing the kinetic energy of moving air. The design wind pressure, on the other hand, is the actual pressure of wind on a square foot of surface and is affected by the ratio between height and width of the surface and by other factors.

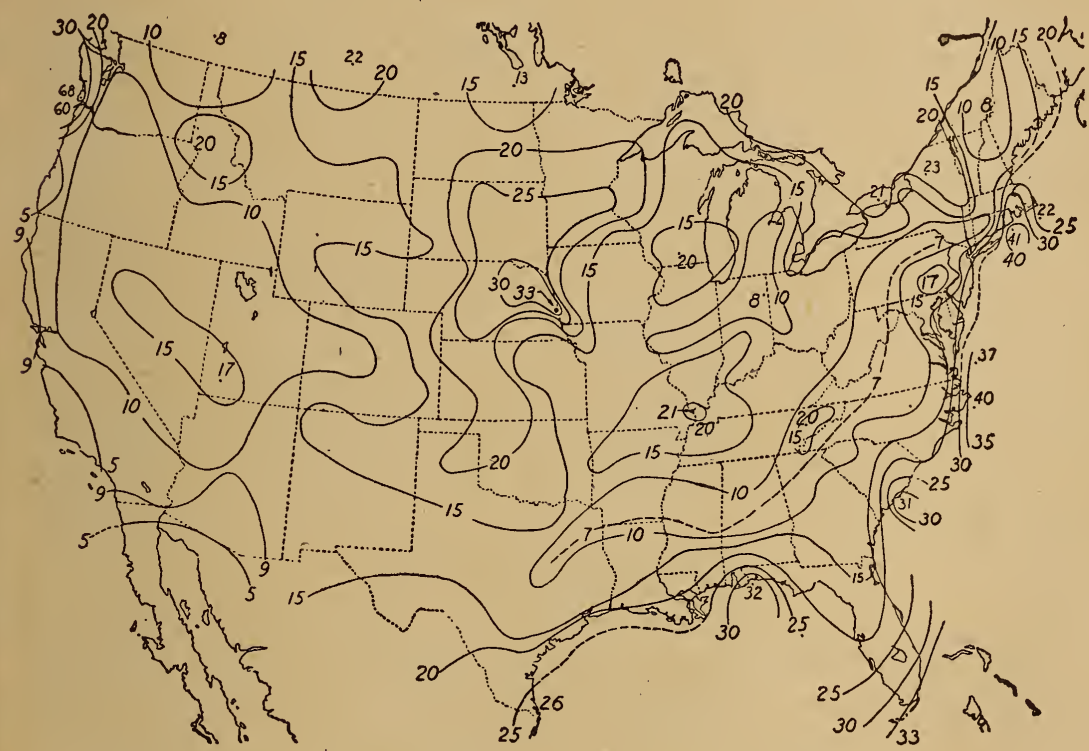

Figure 2.-Velocity pressures (in pounds per square foot).

In arriving at suitable design pressures, without the use of the map on figure 2, the following must be taken into consideration:

(1) Maximum wind velocities averaged over 5 minutes and corrected for instrumental errors as obtained from records of the Weather Bureau for each of 188 stations;

(2) A seventh-root law for the variation of wind velocity with height above the ground; (A review of information on this subject was made by W. W. Pagon and published in Engineering News-Record, May 23, 1935. This law fits in well with both meteorological and laboratory data.)

(3) A gust factor, which has been taken arbitrarily as 1.5 at 30 feet, 1.3 at 500 feet, 1.23 at 1,000 feet, and 1.2 at 1,500 feet and higher; (There is evidence from many sources that the gustiness decreases with height but that it never completely disappears as known, for example, from airplane flights. The values adopted are conservative. In a paper by W. A. Mattice, "A Comparison Between Wind Velocities as Recorded by the Dines and Robinson Anemometers," Monthly Weather Review, vol. 66, August 1938, p. 238-240, the extreme gust 
velocities were 42 percent greater than the fastest single mile, which is itself greater than the 5-minute average. Airplane data show gusts of the order of $40 \mathrm{ft} / \mathrm{sec}$.)

(4) The corresponding velocity pressure which is simply the product of one-half the air density by the square of the resultant design speed, the units being self consistent;

(5) A shape factor or pressure and suction coefficients determined largely from wind-tunnel tests. (The roof data are based on the recommendations in the final report of Subcommittee No. 31, Committee on Steel of the Structural Division, American Society of Civil Engineers, published in the ASCE Proceedings, October 1940, part 2, p. 1713-1739.)

The requirements for general use given in Section 5-1, Minimum Design Pressures, are based on a velocity pressure of $15.4 \mathrm{lb} / \mathrm{ft}^{2}$, this odd value being selected to give a round number value $\left(20 \mathrm{lb} / \mathrm{ft}^{2}\right)$ at 30 -foot height for ordinary buildings with shape coefficient 1.3. A better value of the velocity pressure for any locality could be obtained by (a) obtaining from the nearest Weather Bureau station the maximum true average velocity $V_{h}$ for 5 minutes observed during the existence of the station, corrected for instrumental errors; (b) reducing this value to a height of 30 feet by the formula $V_{30} / V_{h}=(30 / h)^{1 / 7}$, where $h$ is the height of the Weather Bureau anemometer above the ground; (c) increasing $V_{30}$ by 50 percent to allow for gusts, obtaining a design speed for 30 -foot height equal to $1.5 V_{30}$; and (d) computing the corresponding velocity pressure $q_{0}$ at the design speed $V$ from the formula $q_{0}=0.00256 V^{2}$ for $V$ in miles per hour and $q_{0}$ in pounds per square foot. In brief,

$$
q_{0}=0.00576(30 / h)^{2 / 7} V_{h}^{2} .
$$

This formula is based on a standard air density of 0.07635 pound per cubic foot. For localities at considerable elevation above sea level, a reduction in proportion to the actual density would be warranted.

The shape coefficient depends somewhat on the ratio of height to width, but for ordinary buildings the observed values lie between 1.3 and 1.5. The variation with height is a stepwise approximation to the formula given. In the design of the main frame, the wind pressure is assumed to act on the area of the windward wall. It is not ordinarily necessary to distribute the load between windward and leeward walls.

By the use of the map shown in figure 2 some of the operations described above may be dispensed with, since the values shown on the map incorporate most of the steps taken.

After ascertaining from the map, interpolating between isopleths if necessary, the velocity pressure for a given place, this should be multiplied by the following factors to provide for increase in wind velocity with height: 


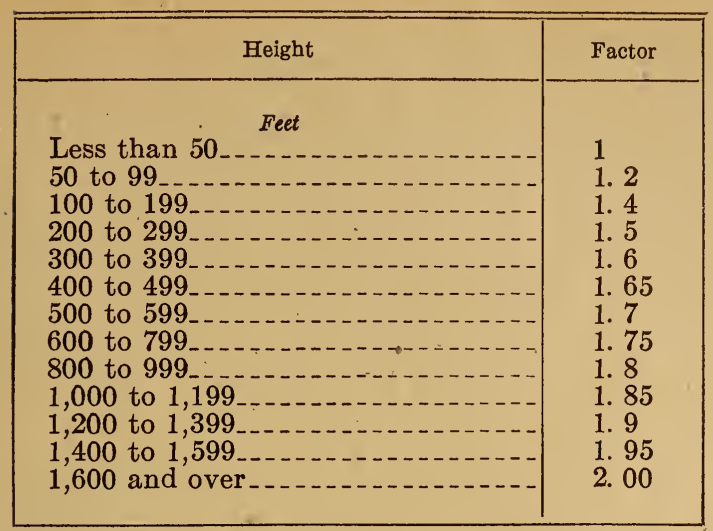

The remaining step is to multiply the velocity pressures thus obtained by the shape factor of 1.3 , which completes the table for insertion in Section 5-1, Minimum Design Pressures, in place of the one presented for general conditions.

"For ordinary buildings and for other buildings whose ratio of height to least width is less than $2 \frac{1}{2}$ to 1 in which the walls, floors, and partitions contribute materially to the lateral rigidity, no design computations or test data need ordinarily be submitted. The building official may, however, require evidence of the safety of the structure. For new types of construction, such as those consisting of prefabricated panels or of unusually light supporting members, the official will in many cases need adequate evidence that the construction is capable of resisting the pressures to which it may be subjected. 5-2. Exterior Walls.-By failure of windows, or otherwise, the interior may be subjected to either the full pressure or suction acting on the building. Hence, any exterior wall should be able to withstand the full wind load acting either inward or outward.

5-3. Roofs. - In case it is desired to make allowance for combined loadings inward and outward on roofs, the following requirements are suggested:

Roofs or sections of roofs shall be capable of withstanding, the following loads acting simultaneously on the windward and leeward slopes:

\begin{tabular}{|c|c|c|}
\hline \multirow{2}{*}{ Slope } & \multicolumn{2}{|c|}{$\begin{array}{l}\text { Exterior load coefficients a (factors to be } \\
\text { applied to loads specified in sec. } 5-1 \text { ) }\end{array}$} \\
\hline & Windward slope & Leeward slope \\
\hline $\begin{array}{l}20^{\circ} \text { or less } \\
\text { Between } 20^{\circ} \text { and } 30^{\circ} \\
\text { Between } 30^{\circ} \text { and } 60^{\circ} \\
\text { Between } 60^{\circ} \text { and } 90^{\circ}\end{array}$ & $\begin{array}{l}-0.60 \\
0.06 \mathrm{~A}-1.8 \\
0.015 \mathrm{~A}-0.45 \\
0.45\end{array}$ & $\begin{array}{l}-0.45 \\
-0.45 \\
-0.45 \\
-0.45\end{array}$ \\
\hline
\end{tabular}

- Positive values indicate an inward load; negative values an outward load. A is the roof slope in degrees. 
The maximum outward force on a gable roof occurs when the wind blows parallel to the ridge. The suction coefficient is about -0.6 . The interior may, however, be subject to full velocity pressure through broken windows or other openings, and hence the force coefficient is 1.6. In view of the recommendations of various insurance groups, somewhat higher values have been adopted, namely one and one-fourth those in Section 5-1, Minimum Design Pressures.

The highest inward loads on gable roofs occur when the interior is subjected to full suction. The force on the lee slope is then zero, and the total inward force on the windward slope has been taken equal to the values in Section 5-1, Minimum Design Pressures, for angles greater than $30^{\circ}$. No inward loads need to be considered for angles less than $30^{\circ}$.

The combined loadings are based on the recommendations given in the final report of Subcommittee No. 31, Committee on Steel of the Structural Division, American Society of Civil Engineers, published in the ASCE Proceedings, October 1940, part 2, p. 1713-1739. The subcommittee also gives recommendations for rounded roofs. It is believed that these combined loadings are critical only for certain types of roof trusses.

5-4. Chimneys.-The value for round chimneys corresponds to a shape coefficient of 0.84 , which is in good agreement with the windtunnel value 0.8 . Hence, the familiar value is retained.

5-5. Signs. - Signs or signboards on the roofs of buildings are exposed to local wind velocities considerably higher than those of the wind itself. The increase is produced by the presence of the building. The reduced value for solid signs on the ground is made in recognition of the decreased velocity pressure to be expected at the limited height within which such signs are generally erected, and the decreased risk of signs located at such height. The recommendations for open signs are based on the work of $\mathrm{O}$. Flachsbart and $\mathrm{H}$. Winter, published in Der Stahlbau, 1934, Nos. 9 and 10, and 1935, Nos. 8, 9, and 10. They take into account the increased load to be expected on the exposed parts of such signs because of the shape factor of these parts.

6 and 7. Earthquake Loads.- It is hoped that the very moderate coefficients of lateral load which have been recommended in Section 6 , Earthquake Loads - General, together with the fact that they are measured in terms of the dead load only of buildings, and are to be used with stresses 50 percent greater than the ordinary working stresses for dead and live load, will make this section suitable for general use. The recommended provisions will give increásed stability of construction with very small increase in cost over that required for poor or even mediocre construction.

From experience it has been found that certain structural features will, if incorporated in the construction, give practical and effective resistance, not only to earthquakes, but to the lateral force of high winds. Among such structural features are the adequate anchorage of floors to masonry walls, reinforced-concrete bond beams placed in the masonry walls just below the floors, and corresponding reinforcedconcrete bond columns placed in the corners of the walls. These special structural features are particularly important in the more common type of building, represented by the one-story commercial buildings with brick walls and timber floors and partitions. Schools 
and churches are examples of buildings of similar construction which often lack lateral stability and are hazardous in earthquakes or wind storms. Buildings of this type are often, if not usually, designed and constructed without the services of a structural engineer. Tall office buildings, on the contrary, are usually designed, insofar as their structural features are concerned, by structural engineers.

Methods of structural design for resistance to earthquakes are much more complex and consequently more controversial in the case of tall multistoried buildings than for low commercial buildings. For the multistoried buildings it seems best that some flexibility in design should be allowed, with the provision that the design for earthquake resistance be required to conform to reasonable and logical analysis and be subject to the approval of the building official. Some experiments made on models of tall buildings indicate that the horizontal shear factors increase with the number of stories. However, the committee feels that the range of experiments has not been sufficiently broad to justify definite recommendations on the subject. For this reason it has been thought best to recommend a constant coefficient for the earthquake factor, as has been done in Section 7-1, Minimum Lateral Load, of the requirements. Again, due to the probability that in the majority of buildings the assumed live load is of ten not realized, it has been thought best to base the earthquake factor on the dead load of the building, except in the case of buildings used for storage purposes, where it is recommended that one-half the live load be counted as dead load.

With reference to the Rossi-Forel and other scales measuring the intensity of earthquakes, and to the history of earthquakes in America and their distribution, attention is invited to the earthquake bulletins of the Seismological Society of America, and to the earthquake catalogs of the United States Coast and Geodetic Survey and of the Seismological Society of America.

The following information provided by the U. S. Coast and Geodetic Survey is presented for the information of local code committees:

\section{EARTHQUAKES IN THE UNITED STATES}

The United States lies partly within the great seismic belt which circumscribes the Pacific Ocean. Practically all parts of the country, however, are subject to earthquakes, as will be seen in figure 3 , which shows the distribution and magnitude of destructive earthquakes within historic time. While the great majority of strong shocks are restricted to rather broadly defined belts, even great earthquakes, such as that at Charleston, S. C., in 1886, may occur in regions generally considered immune on the basis of the historical record.

Earthquake map.-Four grades of intensity are indicated on figure 3 . The smallest dots represent either shocks which were strong enough to overthrow chimneys or shocks perceptible over more than 25,000 square miles. They may be either VII or VIII according to the Rossi-Forel scale of earthquake intensity. (VII indicates the fall of some chimneys, and VIII, IX, and X increasing degrees of destruction up to and including total destruction.) The larger solid dots may be associated with damage ranging from several thousand dollars to a hundred thousand, or to shocks usually perceptible over more than 150,000 square miles. The intensity range is from VIII to IX. The smaller encircled dots represent damage ranging approximately from a hundred thousand to a million dollars, or an affected area greater than 500,000 square miles. The intensity range is IX to $\mathrm{X}$. The larger encircled dots indicate damage of a million dollars or more, or an - affected area usually greater than 1,000,000 square-miles. An intensity of $X$ is indicated. The numeral after a dot indicates the number of shocks that have occurred at or near the location shown. Earthquakes in the border areas of Canada are included as they sometimes result in damage in the United States. 


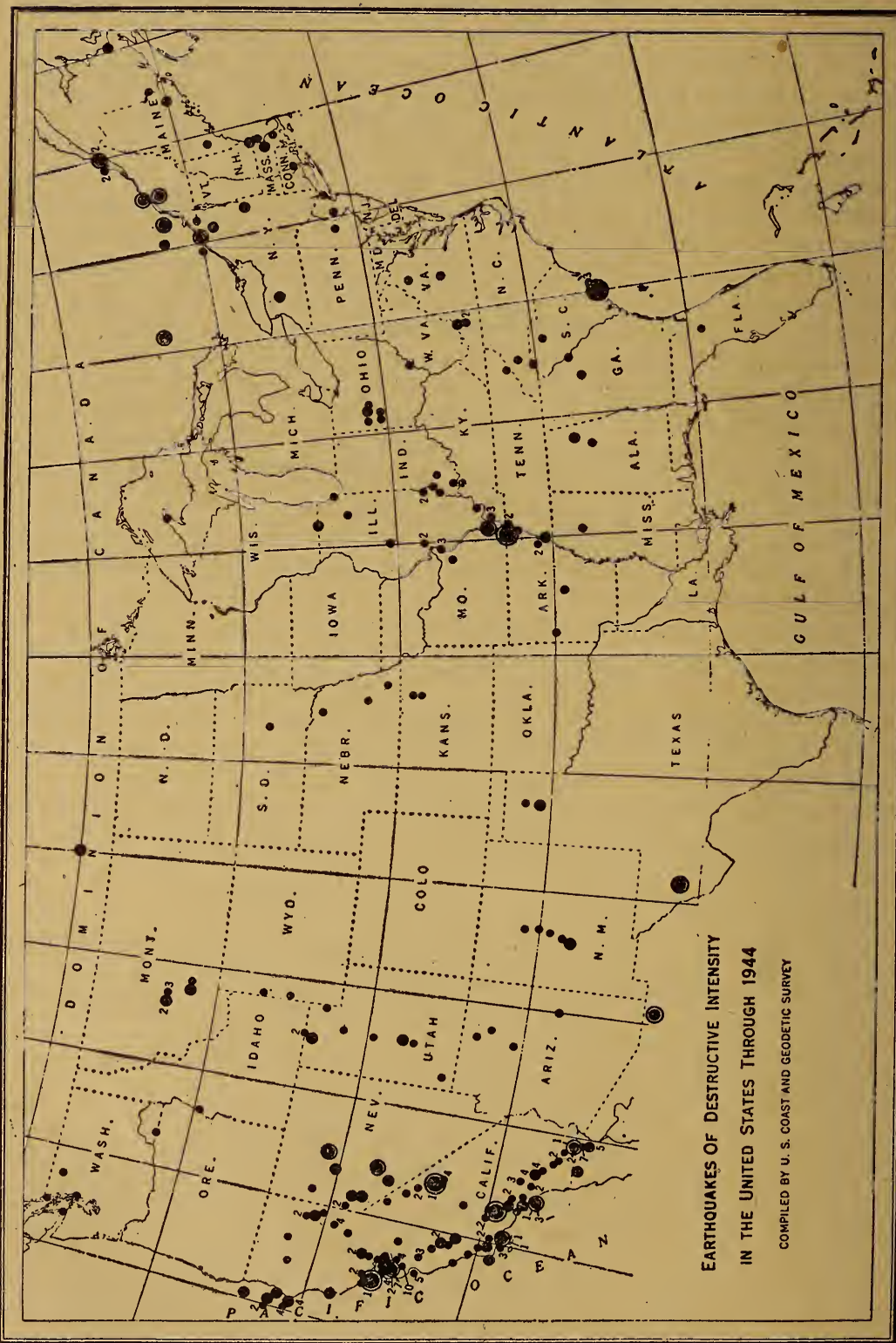

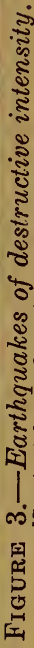


Quite a few have been felt over very large areas in both countries. This is also true for Mexico. The points of origin of many of the earlier shocks are uncertain.

Relation between destructive and potentially destructive shocks.-Relatively weak shocks may cause great damage in congested areas while shocks of heavy energy occurring in uninhabited areas will cause practically no damage. The map must therefore be viewed as having value in showing in a broad way the potential earthquake risk in various areas as based on the historical record. Earthquakes of the Pacific Coast and western mountain region are considered shallower than those in other parts of the country as the ground motions are generally of more destructive character in comparison with those of equal areal extent elsewhere.

In the greatest earthquakes, those of the type indicated by encircled dots on the map, damage was great in 10 percent, heavy in 15 percent, considerable in 30 percent, and minor or negligible in 45 percent of the total number. In very strong shocks, indicated by the large dots, damage was great, in 10 percent, heavy in 20 percent, considerable in 27 percent, and minor or negligible in 43 percent. In strong shocks, those in the small dot category, damage was heavy in 1 percent, considerable in 9 percent, and minor or negligible in 90 percent. In this appraisal, damage over a million dollars is considered great; a hundred thousand dollars or over, heavy; over ten thousand dollars, considerable; and anything less, minor. More than half of the shocks of destructive intensity in the country have occurred in the Pacific Coast and western Nevada area.

References.- This summary is based on reports and records of the United States Coast and Geodetic Survey, principally Serial 609, Earthquake History of the United States, Part I-Continental United States (Exclusive of California and Western Nevada) and Alaska; Part II-Stronger Earthquakes of California and Western Nevada. More detailed information will be found in those reports and in the annual Seismological reports of the Survey. Special reference is made to the January 1939 number of the Bulletin of the Seismological Society of America containing a "Descriptive Catalog of Earthquakes of the Pacific Coast of the United States, 1769 to 1928," by S. D. Townley and M. W. Allen. A comprehensive review and discussion of the earthquake problem in the United States from the insurance and engineering viewpoints is "Earthquake Damage and Earthquake Insurance" by J. R. Freeman (McGraw-Hill Book Co., Inc., New York and London, 1932).

General. - While only about 275 shocks are indicated in figure 3 , the actual number of shocks of all types, felt and unfelt, runs into the thousands annually. As many as a million have been suggested-for the earth as a whole. Neither their ultimate nor immediate cause is known although plausible hypotheses have been advanced, especially in regard to their immediate cause. They cannot be predicted with respect to time and place. Analyses of available statistics have not revealed any periodicity factors of practical value in predicting.

Since 1933 the Coast and Geodetic Survey has made instrumental observations of destructive ground motions. Although the application of this information to the design of structures is handicapped by the need for further laboratory research and more satisfactory analytical methods, progress is being made through the active participation of several engineering research organizations in this specialized field. There is indication that the complex stresses set up in structures during destructive earthquake motions can be expressed in terms of equivalent static forces. Pending the successful completion of this research and the accumulation of sufficient instrumental records of destructive ground motions, the engineer must depend largely on empirical formulas such as recommended in Sections 6 and 7. 
Important earthquakes of the United States and adjoining regions

\begin{tabular}{|c|c|c|c|c|}
\hline Year & Date & Place & $\begin{array}{l}\text { Fin- } \\
\text { isity }\end{array}$ & Remarks \\
\hline 1638 & June 1 & Mass., Plymouth & VIII & $\begin{array}{l}\text { Many stone chimneys down. } \\
\text { Chimneys down in shocks } \\
\text { in } 1662 \text { and probably other } \\
\text { vears. }\end{array}$ \\
\hline 1663 & Feb. 5 & $\begin{array}{l}\text { Canada, Three Rivers, } \\
\text { Lower St. Lawrence } \\
\text { River. }\end{array}$ & $\mathrm{X}$ & $\begin{array}{l}\text { Chimneys broken in Mass. } \\
\text { Bay area. }\end{array}$ \\
\hline 32 & Sept. 15 & Canada, Ontario & IX? & 7 killed at Montreal. \\
\hline 55 & Nov. 18 & Mass., near Cambridge & IX & $\begin{array}{l}\text { Many chimneys down, brick } \\
\text { buildings damaged, stone } \\
\text { fences generally wrecked. } \\
\text { Sand emitted from ground } \\
\text { cracks. Felt from Chesa- } \\
\text { peake Bay to Annapolis, } \\
\text { Nova Scotia. }\end{array}$ \\
\hline 769 & July 28 & $\begin{array}{l}\text { Calif., San Pedro Chan- } \\
\text { nel area. }\end{array}$ & $\mathrm{X}$ & $\begin{array}{l}\text { Major disturbance with many } \\
\text { aftershocks. }\end{array}$ \\
\hline 1790 & (?) & Calif., Owens Valley_- & $\mathrm{X}$ & $\begin{array}{l}\text { Major shock with appearance } \\
\text { of fault scarps. }\end{array}$ \\
\hline 1811 & Dec. 16 & Mo., New Madrid..... & $\mathrm{X}$ & $\begin{array}{l}\text { Greatest United States earth- } \\
\text { quake in historic time. Town } \\
\text { destroyed, great changes in } \\
\text { configuration of ground and } \\
\text { rivers including the Missis- } \\
\text { sippi River. Chimneys down } \\
\text { in Cincinnati. Felt in Bos- } \\
\text { ton. Several killed. }\end{array}$ \\
\hline 1812 & Dec. 8 & $\begin{array}{l}\text { Calif., San Juan Capis- } \\
\text { trano. }\end{array}$ & IX & Church collapsed killing 40 . \\
\hline 1812 & Dec. 21 & Calif., near Lompoc_-- & $\mathrm{X}$ & $\begin{array}{l}\text { Churches and other buildings } \\
\text { wrecked in several towns in- } \\
\text { cluding Santa Barbara. }\end{array}$ \\
\hline 1839 & (?) & Calif., Redwood City & IX? & $\begin{array}{l}\text { Possibly thousands of redwoods } \\
\text { broken off. }\end{array}$ \\
\hline 1857 & Jan. 9 & Calif., Fort $\mathrm{T}$ & $\mathrm{X}$ & $\begin{array}{l}\text { Probably greatest of Pacific } \\
\text { Coast shocks. Originated in } \\
\text { NW corner of Los Angeles } \\
\text { Co. Buildings and large } \\
\text { trees thrown down. }\end{array}$ \\
\hline 1868 & Oct. 21 & Calif., Hayward . & $\mathrm{X}$ & $\begin{array}{l}\text { Many buildings wrecked, } \\
\text { nearly all damaged. Severe } \\
\text { damage at San Leandro and } \\
\text { San Francisco. } 30 \text { killed. }\end{array}$ \\
\hline 1870 & Oct. 20 & $\begin{array}{l}\text { Canada, Montreal to } \\
\text { Quebec. }\end{array}$ & IX & $\begin{array}{l}\text { Widespread. Minor damage } \\
\text { on coast of Maine. }\end{array}$ \\
\hline 1872 & Mar. 26 & Calif., Owens Valley-- & $\mathrm{X}$ & $\begin{array}{l}\text { One of } 3 \text { greatest earthquakes } \\
\text { in Pacific Coast area. 23- } \\
\text { foot fault scarp formed. 27 } \\
\text { killed at Lone Pine out of } \\
300 \text { population; all adobe } \\
\text { houses wrecked. }\end{array}$ \\
\hline 1886 & Aug. 31 & S. C., Charleston & $\mathrm{X}$ & $\begin{array}{l}\text { Greatest earthquake in east- } \\
\text { ern part of country. } 102 \\
\text { buildings destroyed; } 90 \text { per- } \\
\text { cent damaged; nearly all } \\
\text { chimneys down. } \$ 5,500,000 \\
\text { damage About } 100 \text { killed. } \\
\text { Felt at Boston, Chicago and } \\
\text { St. Louis. }\end{array}$ \\
\hline
\end{tabular}


Important earthquakes of the United States and adjoining regions-Continued

\begin{tabular}{|c|c|c|c|c|}
\hline Year & Date & Place & $\left|\begin{array}{l}\text { R-F in- } \\
\text { tensity }\end{array}\right|$ & Remarks \\
\hline 1887 & May 3 & Mexico, Sonora_- & $\mathrm{X}$ & $\begin{array}{l}\text { Widespread in border states. } \\
\text { Chimneys down in several } \\
\text { towns including El Paso and } \\
\text { Albuquerque. }\end{array}$ \\
\hline 1895 & Oct. 31 & Mo., near Charleston & IX & $\begin{array}{l}\text { Felt in Canada, Virginia, Lou- } \\
\text { isiana and South Dakota. } \\
\text { Acres of ground sank and } \\
\text { lake formed. Many chim- } \\
\text { neys demolished. }\end{array}$ \\
\hline 1899 & Dec. 25 & Calif., San Jacinto_- & $\mathrm{X}$ & $\begin{array}{l}\text { Nearly all brick buildings badly } \\
\text { damaged in San Jacinto and } \\
\text { Hemet. Chimneys down in } \\
\text { Riverside. } 6 \text { killed. An- } \\
\text { other severe shock in } 1918 \text {. }\end{array}$ \\
\hline 1906 & Apr. 18 & Calif., San Francisco_. & $\mathrm{X}$ & $\begin{array}{l}\text { Great earthquake and fire. } \\
\text { About } 95 \text { percent of esti- } \\
\text { mated } \$ 400,000,000 \text { damage } \\
\text { due to fre. } 700 \text { killed. } \\
\text { Greatest destruction in San } \\
\text { Francisco, Santa Rosa, and } \\
\text { other towns near San An- } \\
\text { dreas fault. Horizontal slip- } \\
\text { ping along fault, . } 21 \text { feet. } \\
\text { Greatest damage on made } \\
\text { land. }\end{array}$ \\
\hline 1909 & May 26 & Ill., Aurora_ & VIII & Many chimneys down. Felt \\
\hline 1915 & June 22 & Calif., Imperial Valley & IX & $\begin{array}{l}\text { Nearly } \$ 1,000,000 \text { damage. } \\
\text { killed. Well-constructed } \\
\text { buildings were cracked. }\end{array}$ \\
\hline 1915 & Oct. 2 & Nev., Pleasant Valley & $\mathrm{X}$ & $\begin{array}{l}\text { Widespread. Adobe houses } \\
\text { and water tank towers } \\
\text { wrecked. }\end{array}$ \\
\hline 1925 & Feb. 28 & Canada, Murray Bay.- & IX & $\begin{array}{l}\text { Felt in many eastern and cen- } \\
\text { tral states. Damage less } \\
\text { than } \$ 100,000 \text {. }\end{array}$ \\
\hline 1925 & June 27 & Montana, Manhattan & IX & $\begin{array}{l}\text { Landslide blocked entrance to } \\
\text { railroad tunnel. Some build- } \\
\text { ings wrecked and many } \\
\text { chimneys fell. } \$ 300,000 \text { dam- } \\
\text { age. }\end{array}$ \\
\hline 1925 & June 29 & Calif., Santa Barbara & $\mathrm{X}$ & $\begin{array}{l}\$ 6,000,000 \text { damage. } 13 \text { killed. } \\
70 \text { buildings condemned. }\end{array}$ \\
\hline 1929 & Aug. 12 & N. Y., Attica & IX & 250 chimneys toppled. \\
\hline 1929 & Nov. 18 & $\begin{array}{l}\text { Grand Banks, off New- } \\
\text { foundland. }\end{array}$ & $\mathrm{X}$ & $\begin{array}{l}\text { Submarine shock broke } 12 \\
\text { transatlantic cables; some } \\
\text { breaks } 150 \text { miles apart. } \\
\text { Some deaths by seismic sea } \\
\text { wave along Burin Peninsula. } \\
\text { Some chimneys in Canada } \\
\text { toppled. }\end{array}$ \\
\hline 1931 & 20 & $\mathrm{~N}$. & VIII & Chimneys fell. \\
\hline & & Texas, & IX & $\begin{array}{l}\text { All buildings damaged; many } \\
\text { chimneys fell. }\end{array}$ \\
\hline 1932 & Dec. 20 & Nev., Cedar Mountain & $\mathrm{X}$ & $\begin{array}{l}\text { In sparsely settled region. } \\
\text { Widespread. }\end{array}$ \\
\hline 1933 & Mar. 10 & Calif., Longg Beach..... & IX & $\begin{array}{l}\$ 41,000,000 \text { damage; } 120 \text { killed. } \\
\text { Fire damage insignificant. } \\
\text { Greatest strictly earthquake } \\
\text { damage in country. }\end{array}$ \\
\hline
\end{tabular}


Miscellaneous Publications, National Bureau of Standards

Important earthquakes of the United States and adjoining regions-Continued

\begin{tabular}{|c|c|c|c|c|}
\hline Year & Date & Place & $\left|\begin{array}{l}\mathrm{R}-\mathrm{F} \text { in- } \\
\text { tensity }\end{array}\right|$ & Remarks \\
\hline 1934 & Mar. 12 & Utah, Kosmo_.... & IX & $\begin{array}{l}\text { Marked changes in terrain } \\
\text { north of Great Salt Lake. } 2 \\
\text { killed. }\end{array}$ \\
\hline 1935 & Nov. 1 & Canada, Timiskaming - & IX & Widespread. Landslide near \\
\hline 1935 & Oct. 18 & Montana, Helena.- & IX & $\begin{array}{l}\$ 3,500,000 \text { damage. } 4 \text { killed; } \\
\text { less than } 50 \text { injured. More } \\
\text { than half of buildings dam- } \\
\text { aged from } 2.5 \text { to } 100 \text { percent. }\end{array}$ \\
\hline 1941 & June 30 & Calif., Santa Barbara & IX & $\$ 100,000$ damage. \\
\hline 1941. & Nov. 14 & $\begin{array}{l}\text { Calif., Torrance-Gar- } \\
\text { dena area. }\end{array}$ & VIII, & $\begin{array}{l}\text { About } \$ 1,000,000 \text { damage. } 50 \\
\text { buildings severely damaged. }\end{array}$ \\
\hline 1944 & Sept. 5 & $\begin{array}{l}\text { Canada-New York, } \\
\text { Cornwall and Mas- } \\
\text { sena. }\end{array}$ & IX & $\begin{array}{l}\text { On St. Lawrence River. } \$ 1,- \\
500,000 \text { damage reported. } \\
90 \text { percent of chimneys in } \\
\text { Massena destroyed or dam- } \\
\text { aged. }\end{array}$ \\
\hline
\end{tabular}

Washington, April 26, 1945. 

